\title{
Review \\ Calmodulin-Connexin Partnership in Gap Junction Channel Regulation-Calmodulin-Cork Gating Model
}

\author{
Camillo Peracchia * (D) and Lillian Mae Leverone Peracchia \\ Department of Pharmacology and Physiology, School of Medicine and Dentistry, University of Rochester, \\ 601 Elmwood Avenue, Rochester, NY 14642, USA; Imperacchia@gmail.com \\ * Correspondence: camillo.peracchia@urmc.rochester.edu
}

Citation: Peracchia, C.; Leverone Peracchia, L.M. CalmodulinConnexin Partnership in Gap Junction Channel RegulationCalmodulin-Cork Gating Model. Int. J. Mol. Sci. 2021, 22, 13055. https:// doi.org/10.3390/ijms222313055

Academic Editor:

Hideyuki Yamawaki

Received: 8 November 2021

Accepted: 29 November 2021

Published: 2 December 2021

Publisher's Note: MDPI stays neutral with regard to jurisdictional claims in published maps and institutional affiliations.

Copyright: (c) 2021 by the authors. Licensee MDPI, Basel, Switzerland. This article is an open access article distributed under the terms and conditions of the Creative Commons Attribution (CC BY) license (https:// creativecommons.org/licenses/by/ $4.0 /)$.

\begin{abstract}
In the past four decades numerous findings have indicated that gap junction channel gating is mediated by intracellular calcium concentrations $\left(\left[\mathrm{Ca}^{2+}{ }_{i}\right]\right)$ in the high nanomolar range via calmodulin (CaM). We have proposed a CaM-based gating model based on evidence for a direct CaM role in gating. This model is based on the following: CaM inhibitors and the inhibition of CaM expression to prevent chemical gating. A CaM mutant with higher $\mathrm{Ca}^{2+}$ sensitivity greatly increases gating sensitivity. CaM co-localizes with connexins. Connexins have high-affinity CaM-binding sites. Connexin mutants paired to wild type connexins have a higher gating sensitivity, which is eliminated by the inhibition of CaM expression. Repeated trans-junctional voltage (Vj) pulses progressively close channels by the chemical/slow gate (CaM's N-lobe). At the single channel level, the gate closes and opens slowly with on-off fluctuations. Internally perfused crayfish axons lose gating competency but recover it by the addition of $\mathrm{Ca}-\mathrm{CaM}$ to the internal perfusion solution. X-ray diffraction data demonstrate that isolated gap junctions are gated at the cytoplasmic end by a particle of the size of a CaM lobe. We have proposed two types of CaM-driven gating: "Ca-CaM-Cork" and "CaM-Cork". In the first, the gating involves $\mathrm{Ca}^{2+}$-induced $\mathrm{CaM}$ activation. In the second, the gating occurs without a $\left[\mathrm{Ca}^{2+}\right]_{\mathrm{i}}$ rise.
\end{abstract}

Keywords: gap junctions; connexins; innexins; channel gating; calcium; calmodulin; cell communication; cell-to-cell channels; cell coupling; cell uncoupling

\section{Introduction}

Direct ionic communication between electrically excitable cells was discovered in the early 20th century [1,2], but for many decades this form of cell-cell communication was thought to be a property of excitable cells only. Therefore, everyone was surprised when in the 1950s direct cell-to-cell communication was found to exist in the cells of virtually all tissue [3-6]. In the mid-1960s, convincing evidence that this form of cell coupling could be regulated down to complete electrical and metabolic cell-cell uncoupling was reported [3,7-9]. However, some hints of the existence of cell-cell uncoupling mechanisms originated almost a century earlier. Indeed, in 1877 Engelmann reported that damaged cardiac cells became independent from their neighboring cells as they died [10]. This phenomenon, called "healing over", is now known as "cell-to-cell uncoupling", a property of all coupled cells, mediated by the chemical gating mechanism of gap junction channels; rev. in [11-15].

\section{Cytosolic Calcium and Gap Junction Channel Gating}

Nearly a century after Engelmann's discovery [10], Jean Délèze reported that in cut cardiac fibers "healing over" only occurred in the presence of external $\mathrm{Ca}^{2+}[16]$, suggesting that the rise in intracellular calcium concentration $\left(\left[\mathrm{Ca}^{2+}{ }_{i}\right]\right)$ caused by $\mathrm{Ca}^{2+}$ influx played a role in the regulation of gap-junctional communication. Soon after, the $\mathrm{Ca}^{2+}$-role in cell uncoupling was confirmed by evidence that cell-cell communication was lost in cells subjected to treatments that increase the $\left[\mathrm{Ca}^{2+}\right]_{i}[9,15,17-25]$. 
The $\left[\mathrm{Ca}^{2+}\right]_{\mathrm{i}}$ effect on gating has been questioned for more than four decades. Early studies suggested that a $\left[\mathrm{Ca}^{2+}\right]_{\mathrm{i}}$ as high as $40-400 \mu \mathrm{M}$ is needed $[26,27]$. In contrast, numerous more recent reports indicate that a much lower $\left[\mathrm{Ca}^{2+}\right]_{\mathrm{i}}$, ranging from $\sim 100 \mathrm{nM}$ to low $\mu \mathrm{M}$ is effective. Data for the effectiveness of nanomolar $\left[\mathrm{Ca}^{2+}\right]_{i}$ were first reported in a study [28,29] in which [Ca $\left.{ }^{2+}\right]_{\mathrm{i}}$ of $251 \mathrm{nM}$ (at pH 7.4), $400 \mathrm{nM}$ (at pH 7.0) and $2.5 \mu \mathrm{M}$ (at $\mathrm{pH}=6.5$ ) were proven effective in uncoupling cardiac cell pairs, one of which was mechanically perforated to allow the influx of extracellular solutions well buffered for $\mathrm{Ca}^{2+}$ and $\mathrm{H}^{+}$. More recently, a treatment with ionomycin and gramicidin of arterially perfused rabbit papillary muscle uncoupled the cells at $\sim 685 \mathrm{nM}$ or greater $\left[\mathrm{Ca}^{2+}\right]_{\mathrm{i}}[30]$; these data were confirmed in cells subjected to ischemia/reperfusion [30]. Low $\left[\mathrm{Ca}^{2+}\right]_{\mathrm{i}}$ proved effective on gating in many other cells, such as crayfish giant axons [31,32], rat lacrimal cells [33], Novikoff hepatoma cells [34,35], astrocytes [36-38], lens cultured cells [39], pancreatic $\beta$-cells [40], human fibroblasts [41], and Cx43-expressing cultured cells [42]. Mammalian pancreatic and lacrimal gland cells briefly uncoupled when secretion was stimulated by the application of acetylcholine or other secretagogues at concentrations below those required for maximal secretion [43-45], as well as by depolarization or cyclic nucleotide load $[46,47]$. In pancreatic acinar cells, even the treatment with secretagogues at concentrations capable of stimulating maximal secretory activity increases $\left[\mathrm{Ca}^{2+}\right]_{i}$ only

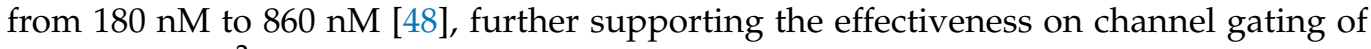
nanomolar $\left[\mathrm{Ca}^{2+}\right]_{\mathrm{i}}$.

We have studied, with $\mathrm{Ca}^{2+}$ - and $\mathrm{pH}$-sensitive microelectrodes, the relationship between junctional electrical resistance $(\mathrm{Rj}),\left[\mathrm{Ca}^{2+}\right]_{\mathrm{i}}$ and $\left[\mathrm{H}^{+}\right]_{\mathrm{i}}$ in crayfish septate axons uncoupled by low $\mathrm{pH}_{\mathrm{i}}$ [32]. Cytosolic acidification $\left(\mathrm{pH}_{\mathrm{i}}=6.3\right)$, caused by the application of $\mathrm{Na}^{+}$-acetate, increased $\left[\mathrm{Ca}^{2+}\right]_{i}$ by approximately one order of magnitude, from resting values of $100-300 \mathrm{nM}$, and greatly increased $\mathrm{Rj}$, indicating that that crayfish gap junctions are sensitive to low $\mu \mathrm{M}\left[\mathrm{Ca}^{2+}\right]_{i}[32]$. The time course of $\mathrm{Rj}$ and $\left[\mathrm{Ca}^{2+}\right]_{i}$ matched well, while that of $\mathrm{Rj}$ and $\left[\mathrm{H}^{+}\right]_{i} \operatorname{did}$ not [32].

In order to more accurately determine the $\left[\mathrm{Ca}^{2+}\right]_{i}$ effective on gating, we studied Novikoff hepatoma cell pairs by double whole-cell clamp [34,35]. In these Cx43-expressing cells, $\mathrm{Ca}^{2+}{ }_{i}$-gating sensitivity was tested by monitoring the decay of junctional conductance (Gj) at different $\left[\mathrm{Ca}^{2+}\right]_{\mathrm{i}}$ (buffered with BAPA), at $\mathrm{pH}_{\mathrm{i}}=7.2$ or 6.1 (buffered with HEPES and MES, respectively). Channel gating was activated by $\left[\mathrm{Ca}^{2+}\right]_{\mathrm{i}}$ ranging from $500 \mathrm{nM}$ to $1 \mu \mathrm{M}$, irrespective of $\mathrm{pH}_{\mathrm{i}}$ [34]. With $\left[\mathrm{Ca}^{2+}\right]_{\mathrm{i}}=0.5-1.0 \mu \mathrm{M}$, the $\mathrm{Gj}$ dropped to $\sim 25 \%$ of the initial values with mean $\tau^{\prime}$ s of 5.9 and $6.2 \mathrm{~min}$, at $\mathrm{pH}_{\mathrm{i}}=6.1$ and 7.2 , respectively. With $\left[\mathrm{Ca}^{2+}\right]_{\mathrm{i}}=3 \mu \mathrm{M}$, the cells uncoupled in $<1 \mathrm{~min}(\tau=\sim 20 \mathrm{~s})$ [34]. The effectiveness of high nanomolar $\left[\mathrm{Ca}^{2+}\right]_{i}$ on gating was confirmed in the same cells with brief (20 s) exposures to $20 \mu \mathrm{M}$ arachidonic acid [35].

Similarly, a $\left[\mathrm{Ca}^{2+}\right]_{\mathrm{I}}<0.5-1 \mu \mathrm{M}$ blocked the cell-cell diffusion of Lucifer Yellow in chicken-lens-cultured cells [39], and nanomolar $\left[\mathrm{Ca}^{2+}\right]_{\mathrm{i}}$ drastically reduced the $\mathrm{Gj}$ in pancreatic $\beta$-cells, with a temperature drop from $37^{\circ}$ to $30^{\circ}$ and an external $\left[\mathrm{Ca}^{2+}\right]_{0}$ rise from $2.56 \mathrm{mM}$ to $7.56 \mathrm{mM}[40]$. Gating sensitivity to $\mathrm{nM}\left[\mathrm{Ca}^{2+}\right]_{\mathrm{i}}$ was also reported in astrocytes injected with Lucifer Yellow and $\mathrm{Ca}^{2+}[36]$. In these cells, nanomolar $\left[\mathrm{Ca}^{2+}\right]_{\mathrm{i}}$ prevented cell-cell dye transfer independently of $\mathrm{pH}_{\mathrm{i}}$; the dye transfer was blocked by $\left[\mathrm{Ca}^{2+}\right]_{\mathrm{i}}$ ranging from 150-600 nM [36]. Consistent with these findings is a report that the addition of $20 \mathrm{mM}$ of BAPTA to the patch pipette solutions substantially improves coupling between astrocytes [37], which indicates that gating may even be sensitive to basal $\left[\mathrm{Ca}^{2+}\right]_{\mathrm{i}}$. Dye coupling was also blocked in cultured astrocytes treated with ionomycin, which increased the $\left[\mathrm{Ca}^{2+}\right]_{\mathrm{i}}$ to $500 \mathrm{nM}$ [38], and similar values were reported in lens-cultured cells [49]. In murine Neuro-2a cells (N2a) expressing Cx43, ionomycin treatment increased the $\mathrm{Ca}^{2+}$-influx and reduced the $\mathrm{Gj}$ by $95 \%[42]$, as the $\left[\mathrm{Ca}^{2+}\right]_{\mathrm{i}}$ increased from $\sim 80$ to $\sim 250 \mathrm{nM}$. All of these data confirm the idea that $\mathrm{Ca}^{2+}{ }_{i}$ is a fine modulator of gap-junctional coupling. 


\section{Evidence for Calmodulin Role in Gap Junction Channel Gating}

As gap junction proteins do not have highly sensitive intracellular $\mathrm{Ca}^{2+}$-binding sites, the data described in the previous chapter strongly suggest that $\mathrm{Ca}^{2+}{ }_{\mathrm{i}}$ affects gating via an intermediate component. Indeed, since the early eighties we have proposed calmodulin $(\mathrm{CaM})$ as the intermediate of the $\mathrm{Ca}^{2+}$ gating effect; rev. in: [50-52].

In 1981, Johnston and Ramón reported that crayfish giant axons lose their cell-cell gating sensitivity to increased $\mathrm{Ca}^{2+}{ }_{\mathrm{i}}$ and/or decreased $\mathrm{pH}_{\mathrm{i}}$ when they are internally perfused [53]. Their data, confirmed by Arellano and coworkers [54], induced them to suggest that a soluble intermediate mediates the $\mathrm{Ca}^{2+} / \mathrm{H}^{+}$-induced cell uncoupling [53]. In the same year, we first suggested $\mathrm{CaM}$ as the soluble intermediate of $\mathrm{Ca}^{2+}{ }_{\mathrm{i}}$-induced gating $[55,56]$. Our idea was also supported by evidence for $\mathrm{CaM}$ binding to the gap junction protein connexin32 (Cx32) and to gap junction fragments from crayfish hepatopancreas [57,58].

In 1988, Arellano and coworkers provided convincing evidence that CaM is in fact the soluble intermediate that had been washed out by the internal perfusion of crayfish axons [54] because when the lateral giant axons were internally perfused with $\mathrm{Ca}-\mathrm{CaM}$ (pCa 5.5; CaM + SIS-B), the Rj increased from the control values of $\sim 60 \mathrm{k} \Omega$ to $500-600 \mathrm{k} \Omega$ in $\sim 60 \mathrm{~min}$ (Figure 1). In contrast, the axons perfused either with $\mathrm{CaM}$ in low $\mathrm{Ca}^{2+}$ solutions ( $\mathrm{pCa}>7$; CaM + SIS-A), with CaM-free high $\mathrm{Ca}^{2+}$ solutions (pCa 5.5; SIS-B) or with Cafree solutions (SIS), maintained the $\mathrm{Rj}$ at control levels during the $60 \mathrm{~min}$ perfusion time (Figure 1). Figure 2 schematically summarizes the results of Arellano and coworkers [54,59]. The same results were reported with either only one axonal segment perfused (Figure 2) or with both segments perfused. Significantly, while $20 \mathrm{~min}$ of the internal perfusion of one axon segment with $1 \mathrm{mM} \mathrm{Ca}^{2+}$ in the absence of CaM did not change the $\mathrm{Rj}$, the subsequent addition of $\mathrm{Na}^{+}$-acetate to the external solution, while maintaining the same internal solution, increased the $\mathrm{Rj}$ to $\sim 400 \mathrm{k} \Omega$ [54]. This is very significant for two reasons: first, it proves that the septum was not damaged by the SIS perfusion; second, it proves that the uncoupling effect of acetate on the intact axon segment is not just due to an increase in $\left[\mathrm{H}^{+}\right]_{\mathrm{i}}[59]$, but rather to an acetate-induced rise in $\left[\mathrm{Ca}^{2+}\right]_{\mathrm{i}}$ resulting from the drop in $\mathrm{pH}_{\mathrm{i}}$ (Figure 2), as also reported by us with different methods [32] (see in the previous).

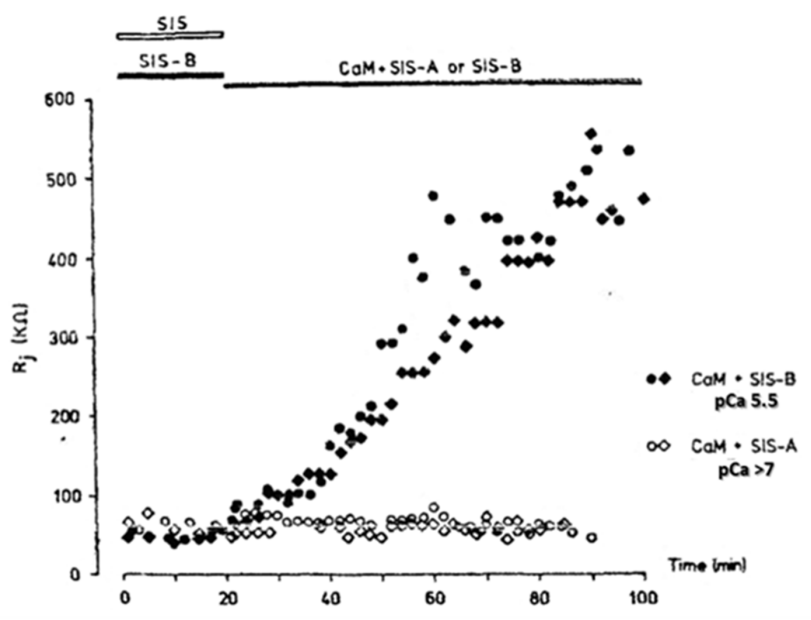

Figure 1. Changes in Junctional Resistance (Rj) in crayfish lateral giant axons in which one axon of the coupled pair was internally perfused with either of the following Standard Internal solutions (SIS): SIS (no added $\mathrm{Ca}^{2+}, 0.1$ mM EGTA, pH 7.1); SIS-A (no added $\mathrm{Ca}^{2+}, 10 \mathrm{mM}$ EGTA, pH 7.1, pCa > 7); SIS-B (1 mM CaCl $2,0.1$ mM EGTA, pH 7.1, pCa 5.5); CaM + SIS-A or SIS-B (10 $\mu$ M CaM, $\mathrm{pH}$ 7.1). Rj does not increase in the absence of $\mathrm{CaM}$, either in the absence of $\mathrm{Ca}^{2+}$ (SIS) or with $1 \mathrm{mM}$ $\mathrm{Ca}^{2+}$ (SIS-B), but does so greatly in the presence of $\mathrm{Ca}^{2+}+10 \mu \mathrm{M}$ CaM (CaM+SIS-B). In the authors' words: "All data points were included in this figure, since the trend illustrated was observed in five other experiments with prolonged perfusion of calmodulin and high calcium". Reproduced with permission from ref. [54]. 


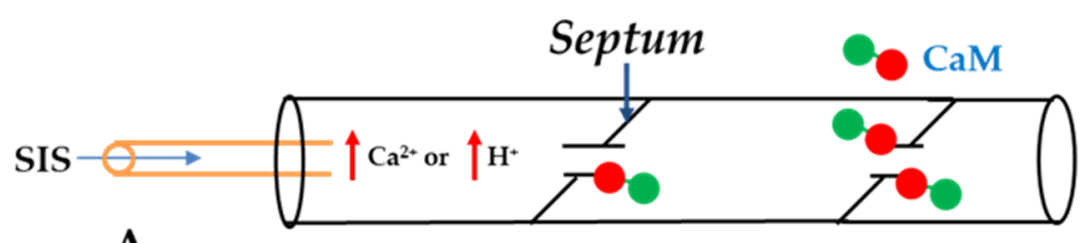

A
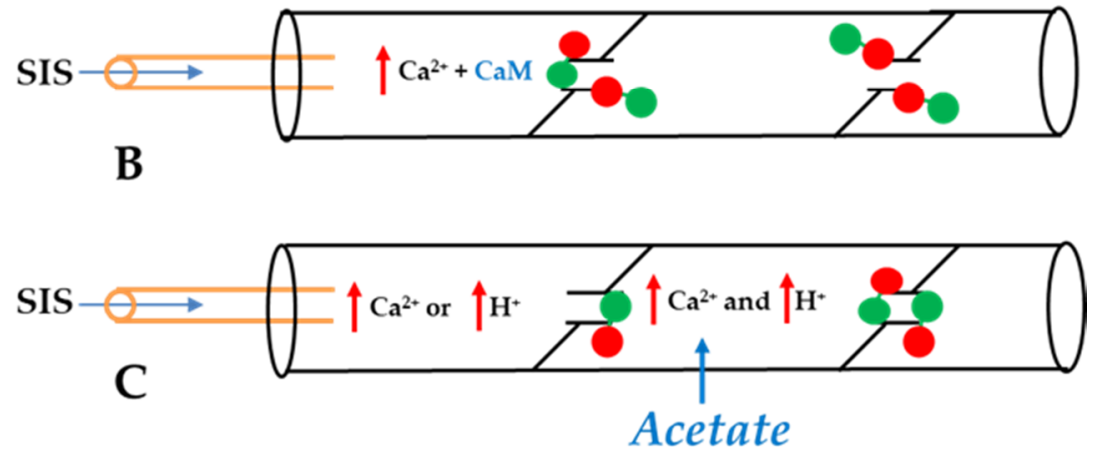

Figure 2. Summary of data from refs. [53,54,59]. While internal perfusion of crayfish lateral giant axons with Standard Internal Solution (SIS) with high $\left[\mathrm{Ca}^{2+}\right]$ and/or $\left[\mathrm{H}^{+}\right]$does not induce channel gating (A), addition of $10 \mu \mathrm{M} \mathrm{CaM}$ to internal solutions with high $\left[\mathrm{Ca}^{2+}\right]$ does (B). Axons internally perfused with high $\left[\mathrm{Ca}^{2+}\right]$ and/or high $\left[\mathrm{H}^{+}\right]$without $\mathrm{CaM}$ uncouple with extracellular perfusion of Standard Extracellular Solution (SES) containing $205 \mathrm{mM}$ Na-acetate (C), as acetate increases $\left[\mathrm{Ca}^{2+}\right]_{\mathrm{i}}$ by increasing $\left[\mathrm{H}^{+}\right]_{i}$ in the un-perfused axon segment. (Red circle: CaM's C-lobe; Green circle: CaM's N-lobe).

Crayfish express innexins rather that connexins, but innexins are very similar to connexins and contain CaM-binding sites. In crayfish giant axons both innexin- 1 and innexin-2 are expressed [60]. Innexin-1 and -2 contain CaM-binding sites at the CT and CL2 domains (Figure 3). The CaM-binding prediction to the CT and CL2 domains of these innexins were identified by means of a computer program developed at the University of Toronto (http: / / calcium.uhnres.utoronto.ca/ctdb/ctdb/sequence.html, accessed on 28 November 2021. Copyright (C) 2021 Ikura Lab, Ontario Cancer Institute. All Rights Reserved).

\begin{tabular}{|c|c|c|}
\hline $\begin{array}{l}\text { Innexin-1 CL2 } \\
\text { Homarus }\end{array}$ & 157 & $\begin{array}{l}\text { REEE TSRRKK DY KN R HNGY K } 187 \\
000999999999999999999990000000\end{array}$ \\
\hline $\begin{array}{l}\text { Innexin-1 CT } \\
\text { Homarus }\end{array}$ & 281 & 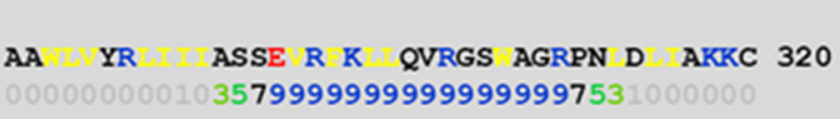 \\
\hline $\begin{array}{l}\text { Innexin-2 CL2 } \\
\text { Homarus }\end{array}$ & 125 & $\begin{array}{ccccc}\text { Y PRY } & \text { K } & \text { EGGK K } & \text { Q NSP } & 154 \\
001234567899999999999987654321 & \end{array}$ \\
\hline
\end{tabular}

Figure 3. Innexins' CaM-binding sites at CL2 and CT domain.

In 1986, Arellano and coworkers also confirmed their earlier data of gating insensitivity to $\mathrm{H}^{+}{ }_{\mathrm{i}}$ [59]. In this study, a glass capillary was inserted into one of the axons and one side of the junction was perfused with solutions of $\mathrm{pH} 7$ or 6 (Figure 2A), while monitoring the $\mathrm{Rj}$. Significantly, the $\mathrm{Rj}$ remained unchanged when the $\mathrm{pH}$ of the perfusate was lowered from 7.1 to 6.0 [59]. We have confirmed the absence of a direct effect of low $\mathrm{pH}_{\mathrm{i}}$ on gating in crayfish axons [32], Xenopus oocyte pairs [61], and Novikoff hepatoma cell pairs [34]. In the Novikoff cells, we monitored the Gj at different pCa $(9,6.9,6.3,6$, and 5.5; buffered with BAPTA) and $\mathrm{pH}_{\mathrm{i}}$ (7.2 or 6.1; buffered with HEPES an MES, respectively). No significant 
difference in the $\mathrm{Gj}$ was observed between $\mathrm{pH}_{\mathrm{i}} 7.2$ and 6.1 as long as the $\left[\mathrm{Ca}^{2+}\right]_{\mathrm{i}}$ was carefully buffered with BAPTA [34].

In the four decades that followed our reports of the early eighties [55,56,62], CaM participation in channel gating has been confirmed by multiple data generated by a variety of experimental procedures that include: treatment with CaM blockers $[42,49,55,56,62-67]$, inhibition of CaM expression [68-70], overexpression of a CaM mutant (CaMCC) with higher $\mathrm{Ca}^{2+}$ sensitivity [71,72], colocalization of $\mathrm{CaM}$ and gap junctions by immune-fluorescence microscopy [71,72] (Figure 4), intracellular perfusion of crayfish axons with CaM-containing solutions [54], and in vitro testing of CaM binding to connexins [57,58,71,72] and synthetic connexin peptides mimicking CaM-binding sites of various connexins [42,52,73-80]; rev. in: [50-52].

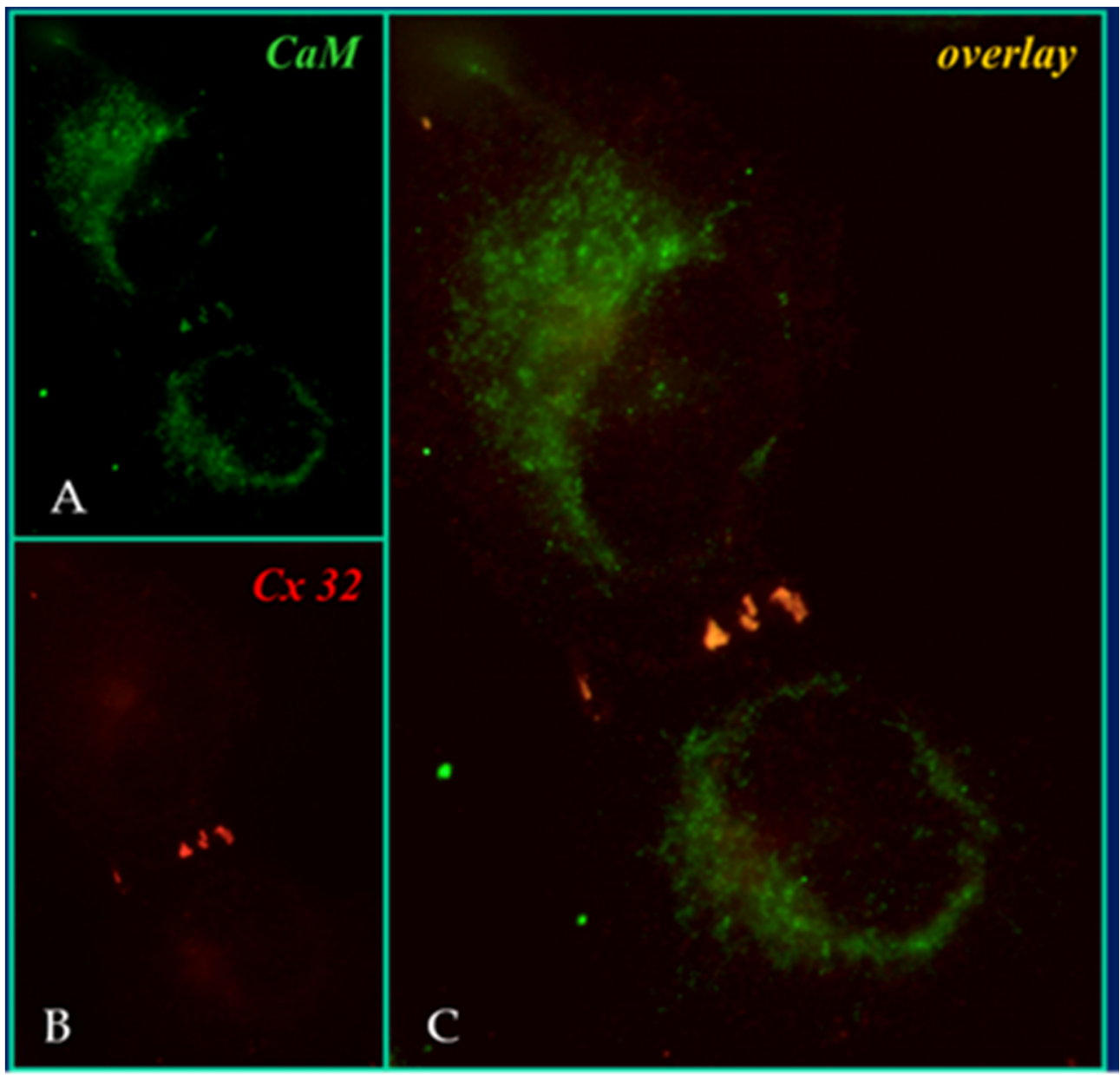

Figure 4. Immuno-fluorescence labeling of CaM (A) and Cx32 (B) in HeLa cells. The overlay of (A,B) is shown in (C). Cx32 and CaM colocalize at three punctuated areas of cell-cell contact. From ref. [72].

After our early evidence for a CaM role in gap junction channel function $[55,62,63,81]$, numerous other membrane channels have been found to directly involve CaM in their gating mechanisms. Indeed, there are an increasing number of channels regulated by CaM. In addition to connexins, they include: voltage-gated calcium (VGCC, $\mathrm{CaV}$ ) channels, sodium (VGSC, NaV) channels, potassium channels (VGPC, KV), small conductance calcium-activated $\mathrm{K}^{+}$channels (SK), inwardly rectifying potassium channels (Kir, IRK), cyclic nucleotide-gated channels (CNG), ryanodine receptors (RyR), and transient receptor potential channels (TRP), rev. in: [82,83], as well as the water channel aquaporin-0 AQP0), also known as the eye lens protein MIP26 [84-90].

$\mathrm{CaM}$ is an acidic protein of 148 amino acids, whose sequence is very well preserved from plants to mammals. It is a dumbbell shaped protein, $\sim 65 \AA$ long, made of two fairly 
spherical lobes of $\sim 35 \times 25 \AA$ in size, called the $\mathrm{N}$-lobe and the C-lobe [91]. A short $\mathrm{NH}_{2}$ terminus is followed by the N-lobe, which is linked to the C-lobe by a flexible amino acid chain. Each of the two lobes has two domains, known as EF-hands [92], which bind $\mathrm{Ca}^{2+}$ with nanomolar affinity. The $\mathrm{Ca}^{2+}$ affinity of the $\mathrm{C}$-lobe is greater than that of the $\mathrm{N}$-lobe by approximately one order of magnitude. $\mathrm{Ca}^{2+}$-binding to $\mathrm{Ca}^{2+}$-free $\mathrm{CaM}(\mathrm{apo}-\mathrm{CaM})$ induces conformational changes that unmask a hydrophobic pocket in each lobe. $\mathrm{Ca}^{2+}{ }_{-} \mathrm{CaM}$ (holo$\mathrm{CaM}$ ) interacts with a receptor domain, usually made of a basic amphiphilic alpha-helix, by binding to it hydrophobically and electrostatically.

\section{Calmodulin-Connexin Interaction-Are There Calmodulin Binding Sites in Connexins?}

Hertzberg and Gilula first reported the CaM binding to Cx32 in gel overlays [57]. Their data were soon confirmed by several studies $[58,76,93]$. The CaM-Cx32 interaction was also indirectly supported by evidence that CaM prevents Cx32 proteolysis by m-calpain [94] and Cx32 phosphorylation by the EGF receptor tyrosine kinase [95]. CaM binding to connexins is also suggested by in vitro data demonstrating CaM participation in the oligomerization of Cx32 into connexons [96].

\section{1. $\mathrm{NH}_{2}$-Terminus (NT) and Initial $\mathrm{COOH}$-Terminus (CT1) CaM-Binding Sites}

In 1988, we first identified two CaM-binding sites in Cx32: one at NT (res. 15-27, in bold letters) and one at CT1 (res. 209-221, in bold letters) [97], by a program developed by Dr. F.W. De Grado (DuPont the Nemours and Co.):

Res. 1-MNWTGLYTLLSGVNRHSTAIGRVWLSVIF-29

Res. 208-EVVYLIIRACARRAQRRSNPPSRKGSGFGH-238

Nine years later, Török and coworkers, studied the binding of CaM to peptides matching the sequences of the NT and CT1 domains of Cx32 by a fluorescent derivative of CaM (TA-CaM) [98] and by equilibrium fluorescence techniques [76]; both peptides interacted with TA-calmodulin in a $\mathrm{Ca}^{2+}$-dependent way [76]. In a later study, the lobespecific binding of CaM to Cx32 peptides was studied by stopped-flow kinetics on $\mathrm{Ca}^{2+}$ binding-deficient mutants of CaM [75]. Peptides that matched the Cx32's NT domain (MNWTGLYTLLSGVNRHSTAIGR, res. 1-22) bound to both the $\mathrm{NH}_{2}$ - and the $\mathrm{COOH}-$ terminal lobes of $\mathrm{CaM}(\mathrm{N}$ - and $\mathrm{C}$-lobes), but with higher affinity to the C-lobe. In contrast, the peptides matching the CT1 domain (AEVVYLIIRACARRAQRRSNP res. 208-227) bound to either CaM lobe, one lobe at a time [75].

We have studied the CaM-binding prediction to the NT and CT1 domains of thirteen murine connexins by means of a computer program developed at the University of Toronto (http:/ / calcium.uhnres.utoronto.ca/ctdb/ctdb/sequence.html, accessed on 28 November 2021. Copyright (c) 2021 Ikura Lab, Ontario Cancer Institute. All Rights Reserved). Figures 5 and 6 show that seven connexins (Cx26, 31,31.1,32, 33, 40, and 43) have a potential CaM binding site at NT and only four connexins (Cx31, 32, 36, and 43) have a potential CaM site at CT1.

The CaM binding to the CT1 of Cx32 was confirmed by measuring the interaction with Isothermal Titration Calorimetry (ITC) and Nuclear Magnetic Resonance (NMR) [99]. In this work, which used a longer chain of amino acids (res. 217-283), both CaM lobes interacted with the peptide. In a later study, the CT domain of Cx43, res. 264-290, has also been found to bind CaM [100]. While the CT domain of Cx35 and Cx36 has been reported to be relevant for gating [101], those of $\mathrm{C} \times 43$ and $\mathrm{C} \times 32$ do not appear to be relevant because Cx43's CT deletion at res. 257 [102] and Cx32's CT deletion by 84\% [61] do not affect gating sensitivity. 


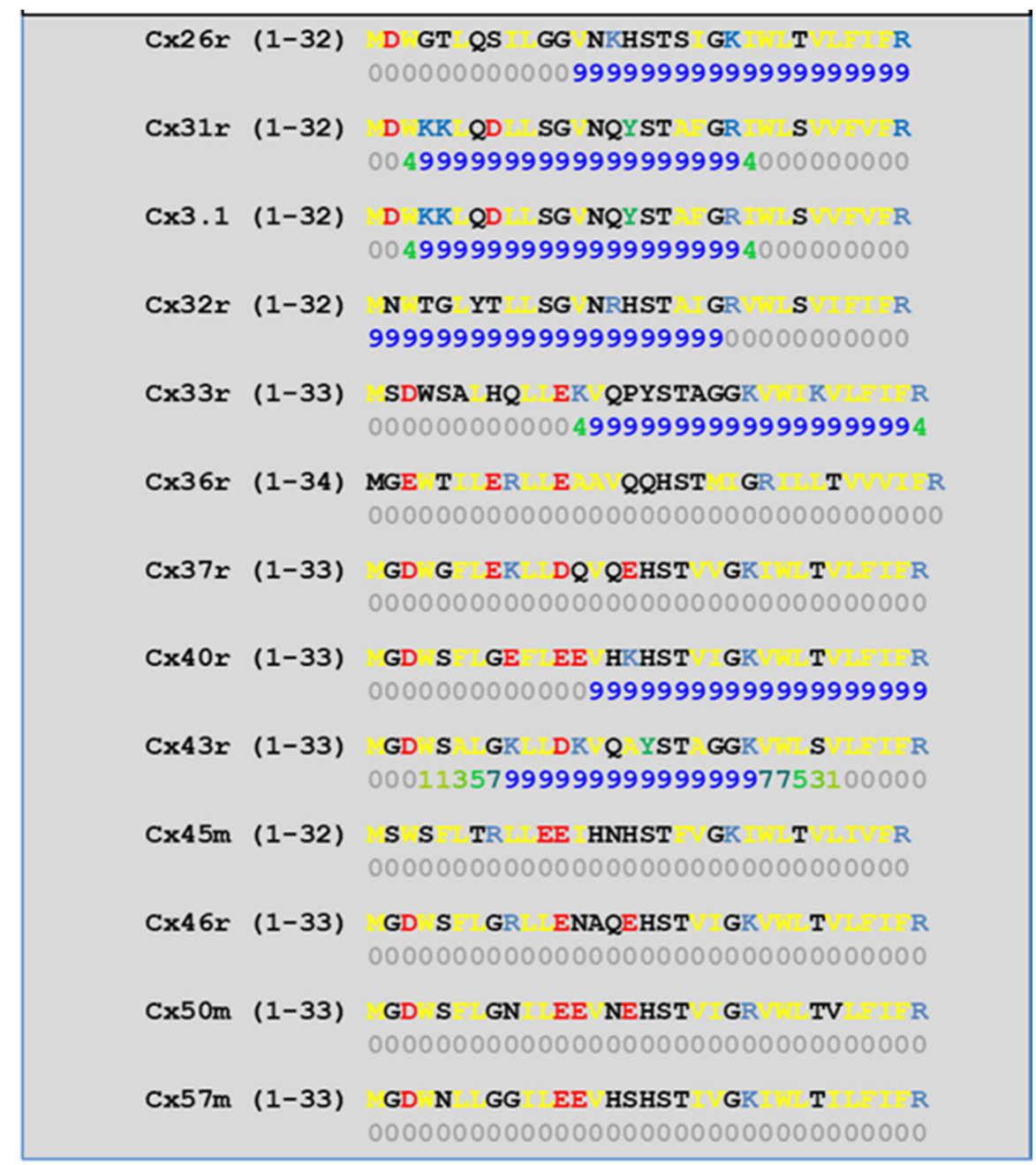

Figure 5. Predicted CaM-binding Site at NT domain.

CaM was reported to bind to the CT1 of mouse Cx35, Cx36, and Cx34.7 [103,104]. The CaM binding of CaM to the CT1 domain of Cx36 was further studied by Nuclear Magnetic Resonance (NMR); this work demonstrated that CaM interacts with a peptide matching the CT1 domain in a typical compact state to eight mostly hydrophobic residues (res. 277-284) [104]. The complex Cx36-CaM preceded the assembly of the Cx36 into plaques and allowed dye coupling [104]. Most relevant is the evidence that CaM inhibitors or W277 residue mutation, a residue relevant for CaM-Cx36 interaction, prevented dye coupling [104]. Data for the interaction between CaM and Cx36 before plaque formation also confirm the role of CaM in gap junction formation [96]. The relevance of the CT1 domain in the gating of Cx35 channels was recently confirmed by Aseervatham and coworkers [101].

The study of Burr and coworkers [103] revealed that the $\mathrm{Ca}^{2+}-\mathrm{CaM}$ dissociation constants $\left(\mathrm{K}_{\mathrm{D}}{ }^{\prime} \mathrm{s}\right)$ of high-affinity sites ranges from $11-72 \mathrm{nM}$, and $\mathrm{K}_{1 / 2}$ 's for the $\mathrm{Ca}^{2+}$ ranges from 3-5 $\mu \mathrm{M}$. A nM Ca ${ }^{2+}-\mathrm{CaM}$ sensitivity is higher than expected, but it might be consistent with evidence for the insensitivity of $\mathrm{C} \times 36$ channels to $100 \% \mathrm{CO}_{2}$, which lowered the $\mathrm{pH}_{\mathrm{i}}$ to $\sim 6.5$ [105]. A possible reason for it is that cytosolic acidification did not increase $\left[\mathrm{Ca}^{2+}\right]_{i}$ to a level sufficient for channel gating. In these Cx36-expressing cells, channel gating occurred with alkalinization, which may result from a high $\mathrm{pH}_{\mathrm{i}}$-induced increase in $\left[\mathrm{Ca}^{2+}\right]_{\mathrm{i}}[106]$. Indeed, cytosolic alkalinization of insect cells increased $\left[\mathrm{Ca}^{2+}\right]_{i}$ and uncoupled the cells at $\mathrm{pH}_{\mathrm{i}}>7.8$ [107]. 


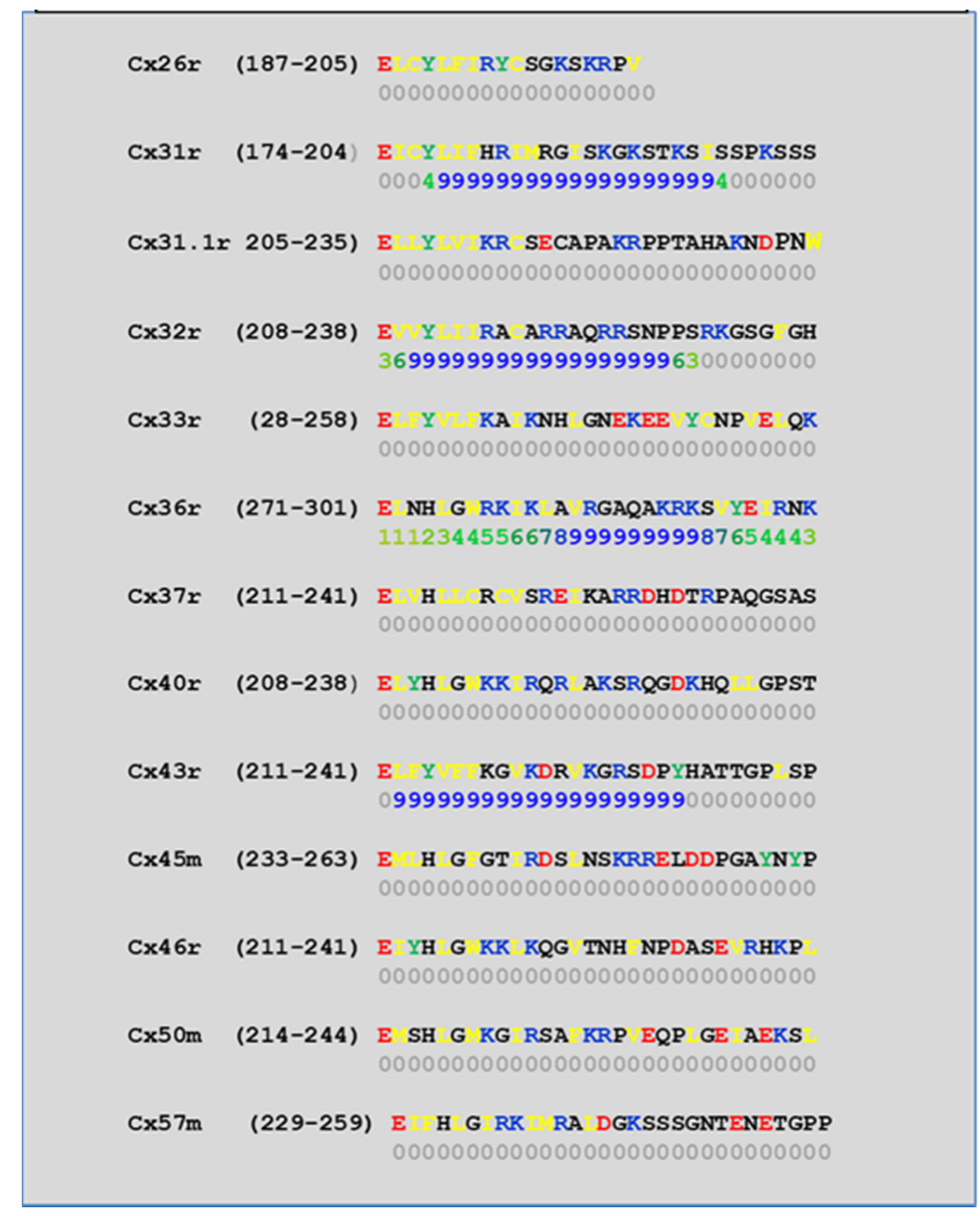

Figure 6. Predicted CaM-binding Site at CT1 Domain.

\subsection{Cytoplasmic Loop (CL) CaM-Binding Sites}

In 1996, we began testing in Xenopus oocyte pairs the $\mathrm{CO}_{2}$ gating sensitivity of channels made of chimeras and mutants of $\mathrm{C} \times 32$ and $\mathrm{C} \times 38$, two connexins whose channels are at the opposite end of the spectrum in chemical gating sensitivity $[108,109]$ (Figure 7). Indeed, a 3 min exposure to $100 \% \mathrm{CO}_{2}$ reduces the $\mathrm{Gj}$ of $\mathrm{C} \times 38$ channels to zero at a maximum rate of $25 \% / \mathrm{min}$, while it reduces that of Cx32 by only 15\% (Figure 7). Even a $15 \mathrm{~min}$ exposure to $100 \% \mathrm{CO}_{2}$ only reduces Cx32's Gj by $~ 50 \%$, at the slow rate of $9 \% / \mathrm{min}[108,109]$.

Channels made of the chimera Cx32/38CL (CL of Cx32 replaced with that of Cx38) matched very well the gating efficiency of the Cx38 channels in the magnitude and in the rate of both the uncoupling and the recoupling (Figure 7). In contrast, the channels expressing the chimera $\mathrm{Cx} 32 / 38 \mathrm{NT}$ (Cx32's NT replaced by that of $\mathrm{C} \times 38$ ) behaved more like Cx32 than Cx38 channels [109]. Channels made of Cx38 are more Vj-sensitive than those of Cx32 $[108,109]$. The Cx32/38CL chimera had a Vj sensitivity closer to that of the channel made of Cx38, while the channels made of Cx32/38NT had very low Vj sensitivity [109]. These data point to the important role that CL plays in the sensitivity of both chemical and Vj gating [108]. 


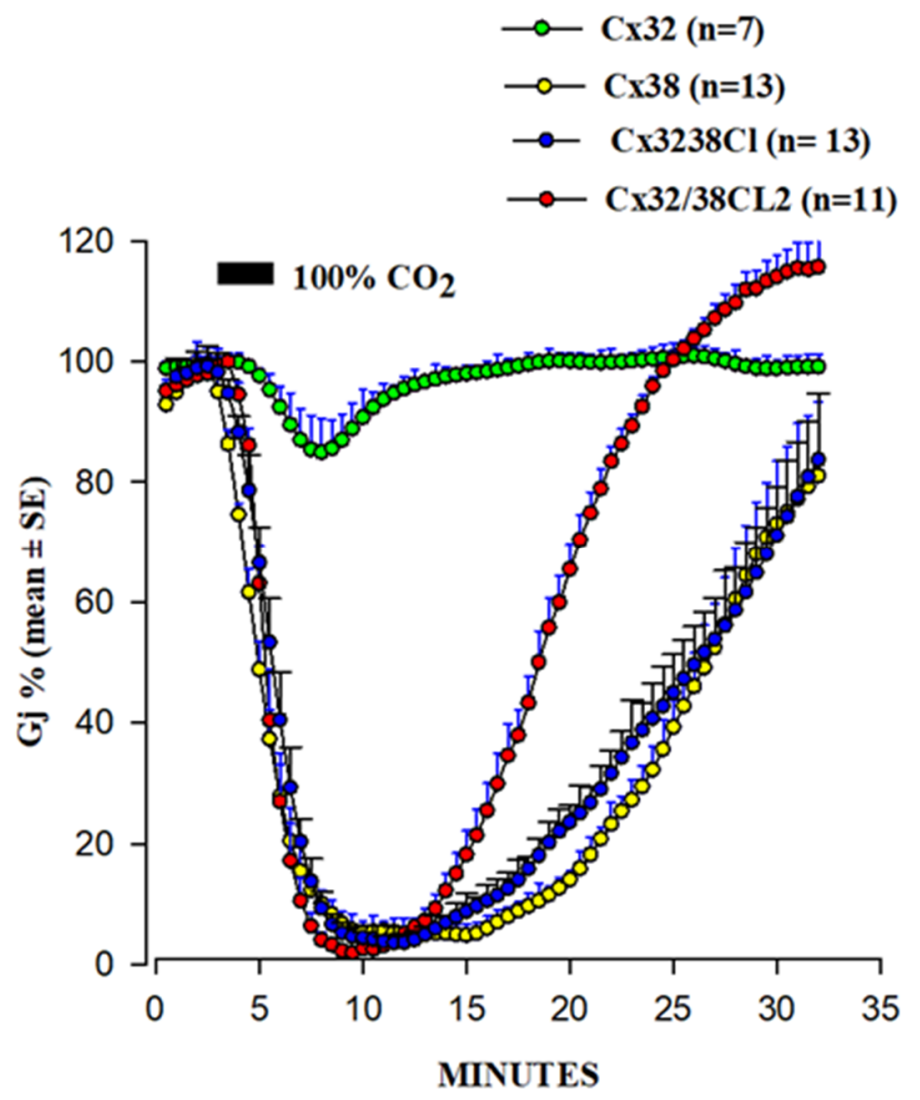

Figure 7. Gj drop induced by $100 \% \mathrm{CO}_{2}$ in oocyte pairs expressing $\mathrm{Cx} 32, \mathrm{C} \times 38$, or $\mathrm{Cx} 32 / 38$ chimeras. Channels made of Cx32/38CL (Cx32's CL replaced with that of Cx38) or Cx32/38CL2 (Cx32's CL2 replaced with that of $\mathrm{Cx} 38$ ) reproduce the gating efficiency of $\mathrm{C} \times 38$ channels, although $\mathrm{Gj}$ recovers faster in Cx32/38CL2 channels. Adapted from refs. [108,109].

To identify in more detail the CL domains most relevant to chemical gating sensitivity, we tested Cx32/Cx38 chimeras in which either the first half (CL1) or the second half (CL2) of Cx38's CL replaced those of Cx32 [108] (Figure 7). Channels made of the chimera Cx32/Cx38CL2 (Cx32 with CL2 of Cx38) matched those made of Cx38 in $\mathrm{CO}_{2}$ sensitivity, but the $\mathrm{Gj}$ recovered more quickly that in the $\mathrm{C} \times 38$ channels, although they matched in the Vj sensitivity of the Cx32 channels (Figure 7). The chimera Cx32/Cx38CL1 (Cx32 with CL1 of $\mathrm{Cx} 38$ ) could not be studied because the functional channels were not expressed. These data indicate that CL1 and CL2 have sequences relevant to fast $\mathrm{Vj}$ and chemical gating, respectively [108]. The importance of CL2 in the sensitivity of chemical gating is consistent with the data from recent studies which have identified a CaM binding site in the CL2s of Cx43, Cx50, and Cx44 (rev. in [52]), as well as in Cx32, Cx35, Cx45, and Cx57 [73,74].

CL2 is likely to be the most relevant CaM binding site in connexins, because in our analysis of CL2 CaM-binding sites (Figure 8) by a computer program developed at the University of Toronto (http:/ / calcium.uhnres.utoronto.ca/ctdb/ctdb/sequence.html, accessed on 28 November 2021. Copyright @ 2021 Ikura Lab, Ontario Cancer Institute. All Rights Reserved), all of the thirteen murine connexins tested contain a potential CaM binding site (Figure 8). 


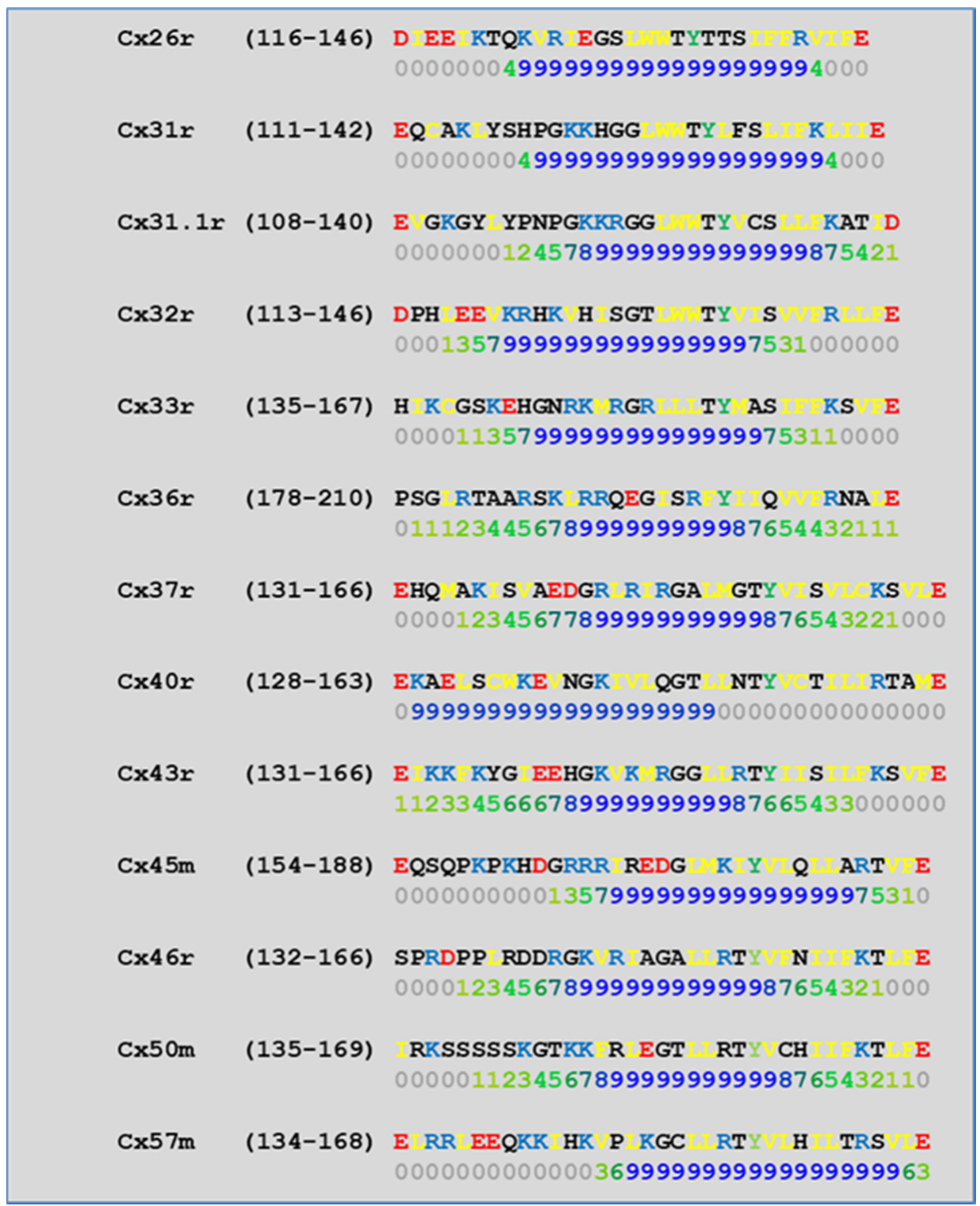

Figure 8. Predicted CaM-binding Site at CL2 domain.

Our data indicating that CL2 contains a domain relevant for chemical gating [108] were first confirmed by the evidence for the presence of a CaM binding site in CL2 of Cx43 (res. 136-158) [80]; a peptide matching this domain bound $\mathrm{Ca}^{2+}-\mathrm{CaM}$ with 1:1 stoichiometry, when studied by surface plasmon resonance, circular dichroism, fluorescence spectroscopy, and NMR. In experiments using far-UV circular dichroism, the $\alpha$-helical content of the peptide increased with the CaM binding. This was further confirmed by fluorescence and NMR studies, which demonstrated that both the CaM and the peptide change in conformation with the peptide-CaM complex formation. The $\mathrm{K}_{\mathrm{D}}$ of peptide binding to $\mathrm{CaM}$ in physiologic potassium concentration ranges from $0.7-1 \mu \mathrm{M}$. Upon peptide binding to $\mathrm{CaM}$, the $\mathrm{K}_{\mathrm{D}}$ of $\mathrm{Ca}^{2+}$ for CaM dropped from $2.9 \pm 0.1 \mu \mathrm{M}$ to $1.6 \pm 0.1 \mu \mathrm{M}$, and the Hill coefficient $\left(n_{\mathrm{H}}\right)$ rose from $2.1 \pm 0.1$ to $3.3 \pm 0.5$ [80]. For testing the gating competence of Cx43 mutants without the CaM-binding site, two mutants, bound to EYFP (a fluorescent protein), were tested in HeLa cells. Significantly, the absence of the CaM-binding site at CL2 eliminated the $\mathrm{Ca}^{2+}$-dependent gating, which was consistent with the idea that the CL2 domain spanning res. 136-158 contains the CaM-binding domain most important for the $\mathrm{Ca}^{2+}$-dependent gating of the $\mathrm{C} \times 43$ channels [80]. 
The importance of the CaM-binding site at CL2 was further proven with the Cx43 [42], Cx50 [78], or Cx44 [79] channels; rev. in [52]. A study [110] employed a synthetic peptide that matched the CL2's CaM-binding site of Cx43 (res. 144-158 KVKMRGGLLRTYIIS) to evaluate by small-angle $X$-ray scattering of the $\mathrm{Ca}^{2+}$-induced changes in the conformation of the CaM-peptide complex. Upon peptide binding, CaM lost the dumbbell shape and became more globular, suggesting that CaM interacts with the peptide in a typical 'collapsed' conformation [110].

$\mathrm{Xu}$ and coworkers [42] studied whole-cell patch-clamp N2a cells expressing human $\mathrm{Cx} 43$ or $\mathrm{Cx} 40$. The ionomycin treatment of $\mathrm{N} 2 \mathrm{a}$ cells expressing $\mathrm{Cx} 43$ tripled $\left[\mathrm{Ca}^{2+}\right]_{\mathrm{i}}$ and induced a 95\% drop in the Gj; in contrast, in Cx40-expressing N2a cells ionomycin did not significantly change the $\mathrm{Gj}$. The apparent gating incompetence of human Cx40 [42] seems to contradict our evidence for the significant chemical gating sensitivity of the rat Cx40 [111], but it might be consistent with the $\mathrm{Ca}^{2+}-\mathrm{CaM}$-gating role. Indeed, a computer analysis of CL2's putative CaM-binding sites shows that the absence of the residues V38 and V43 in rat Cx40, which are replaced by G39 and A44, respectively, in the human Cx40 may be the reason for the predicted inability of the CL2 domain of human Cx40 to bind CaM [50]. With $\mathrm{Cx} 43$, the $\mathrm{Ca}^{2+}$-induced $\mathrm{Gj}$ drop was prevented by CDZ treatment and reversed by the addition of $10 \mathrm{mM}$ EGTA to $\mathrm{Ca}^{2+}$-free saline [42]. Addition to the pipette solutions of a Cx43 peptide matching the CL2 CaM-binding domain (res. 136-158) also prevented gating, whereas neither a scrambled peptide nor the $\mathrm{Ca}^{2+} / \mathrm{CaM}$-dependent kinase II inhibitory peptide (res. 290-309) did [42]. These data confirm that the CaM-binding domain of CL2 is a key player in Cx43's gating. Table 1 summarizes the potential CaM-binding sites of thirteen murine connexins.

Table 1. Predicted CaM-binding sites in connexins.

\begin{tabular}{cccc}
\hline Connexin & NT Site & CL2 Site & CT1 Site \\
\hline Cx26r & Yes & Yes & Yes \\
\hline Cx31r & Yes & Yes & \\
\hline Cx31.1r & Yes & Yes & Yes \\
\hline Cx32r & Yes & Yes & Yes \\
\hline Cx33r & Yes & Yes & \\
\hline Cx36r & & Yes & Yes \\
\hline Cx37r & & Yes & \\
\hline Cx40r & Yes & Yes & \\
\hline Cx43r & Yes & Yes & \\
\hline Cx45m & & Yes & \\
\hline Cx46r & & Yes & \\
\hline Cx50m & & Yes & \\
\hline Cx57m & &
\end{tabular}

\subsection{CaM Is Anchored to Connexins at Resting $\left[\mathrm{Ca}^{2+}\right]_{i}$}

A number of reports indicate that $\mathrm{CaM}$ is anchored to connexins at resting $\left[\mathrm{Ca}^{2+}\right]_{\mathrm{i}}$; rev. in [51]. This has recently been confirmed by in vitro experiments that tested the CaM interaction with peptides matching the CL2's CaM binding site of Cx32, Cx35, Cx45 and $\mathrm{Cx} 57$, in the presence and absence of $\mathrm{Ca}^{2+}[73,74]$. In this study, fluorescence changes of the FRET-probe DA-CaM and $\mathrm{Ca}^{2+}$-sensitive TA-CaM were recorded by fluorescence spectroscopy and stopped-flow fluorimetry [98] at physiological ionic strength $(\mathrm{pH} 7.5$, $20{ }^{\circ} \mathrm{C}$ ). Both the $\mathrm{Ca}^{2+}$-dependent and the $\mathrm{Ca}^{2+}$-independent interactions were found, with the following $\mathrm{K}_{\mathrm{D}}$ values (Table 2). 
Table 2. CaM binding to CL2.

\begin{tabular}{ccc}
\hline & $\mathbf{K}_{\mathbf{D}}\left(\right.$ with $\left.\mathbf{C a}^{2+}\right)$ & $\mathbf{K}_{\mathbf{D}}\left(\mathbf{C a}^{2+}\right.$-Free $)$ \\
\hline Cx32 & $40 \pm 4 \mathrm{nM}$ & $280 \pm 10 \mathrm{nM}$ \\
\hline Cx35 & $31 \pm 2 \mathrm{nM}$ & $2.67 \pm 0.09 \mu \mathrm{M}$ \\
\hline Cx45 & $75 \pm 4 \mathrm{nM}$ & $78 \pm 1 \mathrm{nM}$ \\
\hline Cx57 & $60 \pm 6 \mathrm{nM}$ & $52 \pm 14 \mathrm{nM}$ \\
\hline
\end{tabular}

FRET measurements demonstrated partial compaction of DA-CaM (54-70\% quenching with $\mathrm{Ca}^{2+}$ and 33-62\% quenching in $\mathrm{Ca}^{2+}$-free solutions). The kinetic data showed a twostep process: rapid binding followed by isomerization. This supports the idea that the CaM is anchored to the Cxs and upon stimulation becomes fully bound to them [73,74].

Significantly, the CL2 peptides of Cx45 and Cx57 bind to the CaM with similar high affinities, both with and without $\mathrm{Ca}^{2+}$. This seems to suggest that the CaM is anchored by the C-lobe at the resting $\mathrm{Ca}^{2+}$, either in a $\mathrm{Ca}^{2+}$-free or in a $\mathrm{Ca}^{2+}$-bound state. However, one should realize that in vitro peptide-CaM interaction does not say much about the actual channel gating mechanism and the potential conformational changes in connexins that result in channel gating.

\section{Calmodulin-Cork Gating Model}

In 2000, we proposed a CaM-based "cork-type" mechanism of gap junction chemical gating [112]. This "cork" model envisions a physical obstruction of the cytoplasmic mouth of the channel by a CaM lobe $[19,50,112,113]$, probably combined with conformational changes in the connexins, caused by $\mathrm{Ca}^{2+}-\mathrm{CaM}$ binding to the gating site. The model is based on numerous findings that suggest a direct CaM role in gating; rev. in [50-52,113]. Experimental evidence indicates that the chemical/slow gate is a sizable, negativelycharged particle, likely to be a CaM lobe $[69,114]$.

There are many reasons why we think that CaM is the most likely gating candidate. $\left[\mathrm{Ca}^{2+}\right]_{\mathrm{i}}$ in the high $\mathrm{nM}$ to low $\mu \mathrm{M}$ values activates chemical gating; rev. in [19,52]. In view of the fact that the cytoplasmic domains of connexins do not contain sequences able to bind $\mathrm{Ca}^{2+}$ at such low concentrations, the effect of $\mathrm{Ca}^{2+}{ }_{\mathrm{i}}$ on the channel gating is most likely mediated by a CaM-like protein, most likely CaM itself. Indeed, CaM binds to connexins $[52,57,58,71,72,77,115]$ which in fact have CaM-binding sites; most of the sites are at the second half of the cytoplasmic loop (CL2), but some are also at the $\mathrm{NH}_{2}$-terminus (NTsite) and at the $\mathrm{NH}_{2}$-end of the $\mathrm{COOH}$-terminus (CT1); rev. in [19,52,75,113]. Most relevant for gating are likely to be the CL2 and NT sites [52,73-75,77,108,109]. Peptides mimicking the CaM-binding site sequences located at CL2, NT, and CT1 of several connexins bind $\mathrm{Ca}^{2+}-\mathrm{CaM}$ with high affinity $[42,52,73-76,78-80,99,103]$. Most important is the binding of CaM to the CL2 domain, which has been experimentally confirmed by Jenny Yang's team for Cx43 [80], Cx44 [79] Cx50 [78], and Cx45 [77] and by Katalin Török's team for Cx32, Cx35, Cx45, and Cx57 [73,74]. CaM and connexins co-localize at gap junctions (Figure 4) and intracellular sites $[71,72,77,104,116]$. Recently, the direct binding of CaM to Cx45 has been visualized in living cells by Bioluminescence Resonance Energy Transfer (BRET) [77]; the interaction of CaM and Cx45 was $\mathrm{Ca}^{2+}$-dependent and prevented by W7; the CL2's CaM binding site (res. 164-186) was confirmed by a study reporting its high-affinity interaction $\left(\mathrm{K}_{\mathrm{D}}=\sim 5 \mathrm{nM}\right)$ with a peptide matching the CL2 domain of Cx45's CL2, tested with a fluorescence-labeled CaM [77]. On the other hand, however, another study provided evidence for both $\mathrm{Ca}^{2+}$-dependent and $\mathrm{Ca}^{2+}$-independent CaM-binding to the CL2 domains of Cx45, Cx32, Cx35, and Cx57 [73,74]. The $\mathrm{Ca}^{2+}$-independent binding of CaM to the CL2 domain $[73,74]$ confirms earlier data suggesting that the CaM is anchored to the Cxs at normal $\left[\mathrm{Ca}^{2+}\right]_{\mathrm{i}}(\sim 50 \mathrm{nM})[69,71,72,77]$. Each of the two negatively-charged CaM lobes is $\sim 25 \times 35 \AA$ in size [91], which is the approximate size of the positively-charged cytoplasmic mouth (vestibule) of the channel [117-119] (Figure 9). So, a CaM lobe would fit nicely in the mouth (vestibule) of the connexon (Figure 9B). Evidence from a three-dimensional electron 
density map of isolated gap junctions, which display crystalline (hexagonal) channel arrays (see in the following), studied by X-ray diffraction, proves that the channels are in a closed state as they are inaccessible to sucrose due to a blocking particle at both channel ends similar in size to a CaM lobe [120-122] (see in the following). Significantly, in a doublewhole-cell-clamp (single-channel) study the chemical/slow gate opens and closes fully and very slowly (transition time $=\sim 10 \mathrm{~ms}$ ) [123] and the open-to-closed channel transitions, and vice versa, often displayed fluctuations [123]. This further supports the idea that a large particle may transiently flicker in and out of the mouth of the channel before closing the channel completely [123].

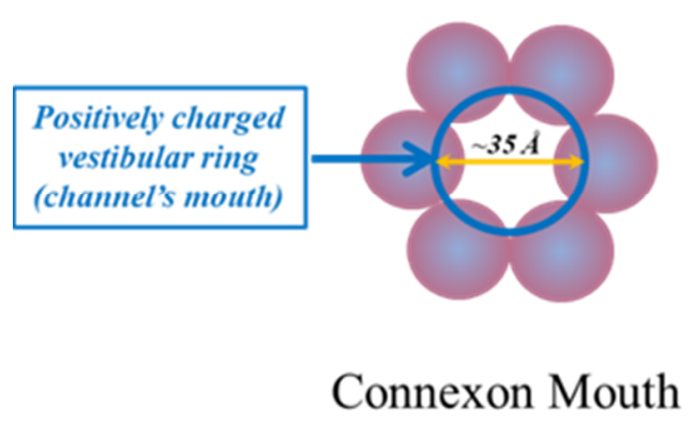

A

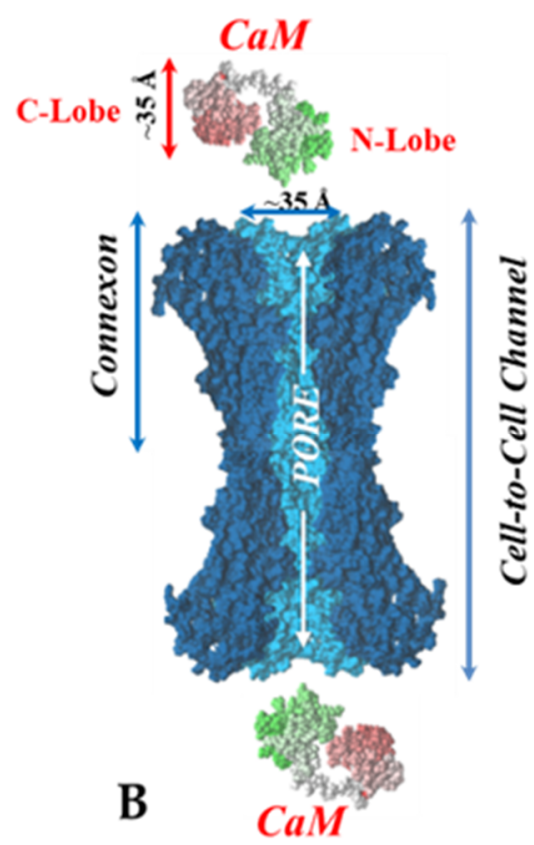

Figure 9. Both the positively charged channel's mouth (A) and the negatively charged CaM lobes (B) are $\sim 35 \AA$ in diameter. Therefore, a CaM lobe could fit well in the channel's mouth (vestibule) and electrostatically interact with it. In $B$, the channel is split along its length to display the pore diameter (light blue area) along the channel's length. Both CaM and connexon images (B) were provided by Dr. Francesco Zonta (Venetian Institute of Molecular Medicine, VIMM, University of Padua, Italy).

We are proposing two types of CaM-mediated cork-gating mechanism: "Ca-CaMcork" and "CaM-cork". In the former, the gating involves $\mathrm{Ca}^{2+}$-induced CaM activation. In the latter, gating would occur without a $\left[\mathrm{Ca}^{2+}\right]_{i}$ rise above the resting values and in most cases would require either a connexin mutation $[69,114]$ or the application of large $\mathrm{Vj}$ gradients [124].

\subsection{Ca-CaM-Cork Gating Mechanism}

The Ca-CaM-cork gating envisions that a $\left[\mathrm{Ca}^{2+}\right]_{i}$ rise above resting levels $(>\sim 50 \mathrm{nM})$ causes a CaM lobe (most likely the N-lobe) to block the channel's mouth (vestibule) by electrostatically and hydrophobically interacting with a receptor site located at CL2 or NT (CaM-gating site) (Figure 10). This interaction is also likely to induce a change in the connexin conformation. The CaM-gating site is likely to be close the channel's mouth (vestibule) $[19,112]$. At basal $\left[\mathrm{Ca}^{2+}\right]_{\mathrm{i}}(\sim 50 \mathrm{nM})$, the CaM is believed to be anchored to each of the six connexins by one of its lobes (most likely the C-lobe), while the other lobe is likely to be free, but unable to access the channel's mouth at resting $\left[\mathrm{Ca}^{2+}\right]_{\mathrm{i}}$ (Figure 10). 


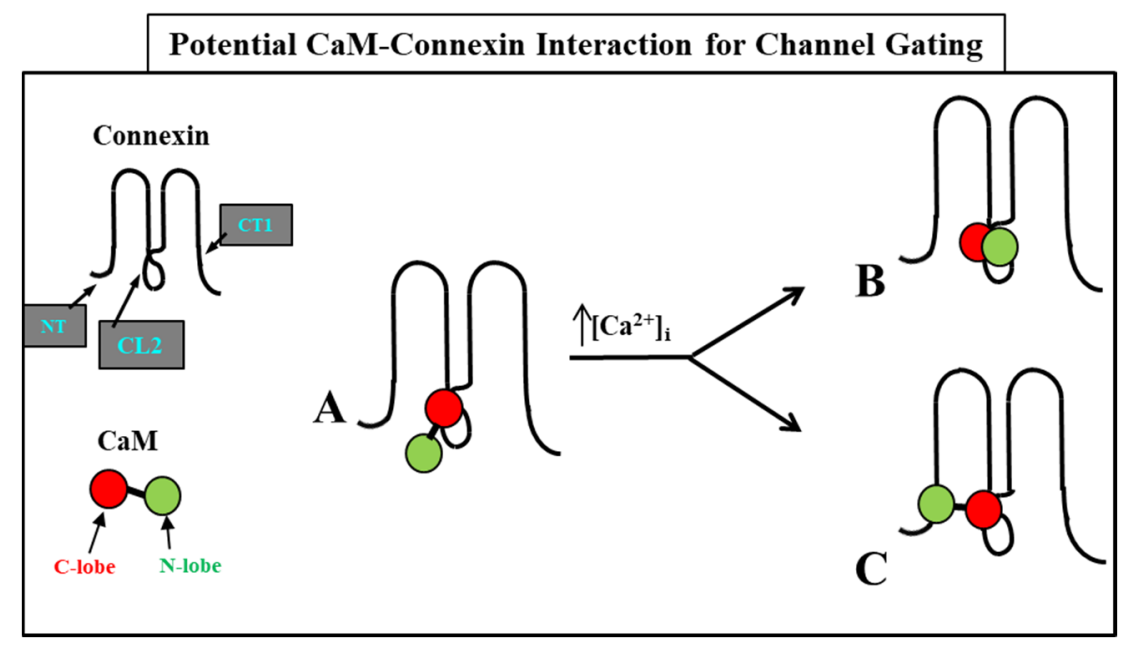

Figure 10. We believe that CaM is anchored to CL2 by its C-lobe lobe $(\mathbf{A}) \cdot\left[\mathrm{Ca}^{2+}\right]_{\mathrm{i}}>\sim 50 \mathrm{nM}$ are believed to cause the N-lobe to gate the channel by interacting hydrophobically and electrostatically with CL2 (B) or NT (C) domains of the same connexin or another connexin of the same connexon (trans-domain or trans-subunit interaction, respectively), resulting in pore blockage (cork gating model).

The $\mathrm{Ca}^{2+}$-affinity constant of the C-lobe's EF-hand pair is almost one order of magnitude greater than that of the N-lobe's EF-hand pair $\left(\mathrm{K}_{\mathrm{D}(\mathrm{app})}=5.6 \mu \mathrm{M}\right.$ and $32 \mu \mathrm{M}$ for C-lobe and N-lobe, respectively) $[125,126]$. Therefore, the N-lobe most likely interacts with the channel's gating site (CL2 or NT) only with an increase in $\left[\mathrm{Ca}^{2+}\right]_{\mathrm{i}}$ above the resting values $(>\sim 50 \mathrm{nM})$ (Figure 10).

The Ca-CaM-cork gating is likely to be either reversible or irreversible (Ca-CaM locked gate; see in the following). The former may be activated by a moderate increase in $\left[\mathrm{Ca}^{2+}\right]_{\mathrm{i}}$, while the latter may result from a greater increase and/or a more prolonged $\left[\mathrm{Ca}^{2+}\right]_{\mathrm{i}}$ rise. We believe that the ultrastructural correlate of the "irreversible Ca-CaM locked gate" is reflected by gap junctions displaying "crystalline" (hexagonal) channel arrays [18,127-130] (see in the following).

\subsection{CaM-Cork Gating Mechanism}

\subsubsection{CaM-Cork Gating in Mutant-Cx32 Channels}

The gating behavior of Cx32/mutant heterotypic channels [69,114], Cx45 homotypic channels [70], and Cx32 homotypic channels exposed to large Vj gradients [124] may exemplify the CaM-cork gating mechanism. At the mutant side of the Cx32/mutant channels, the CaM's N-lobe is believed to engage with the channel's mouth at basal $\left[\mathrm{Ca}^{2+}\right]_{i}$ $(\sim 50 \mathrm{nM})$ as the mutations might have caused the channel's mouth to be unprotected, making it accessible to the CaM's lobe. The CaM lobe would electrostatically interact with the positively charged channel's mouth so that it could be displaced by $\mathrm{Vj}$ positive at the mutant side $[69,114]$. Indeed, the connexins' cytoplasmic domain has a high number of basic/acidic residues; in Cx32, for example, if we neglect most of the CT, whose deletion by over $80 \%$ does not affect chemical gating [61], one finds 18 basic and 6 acidic residues per connexin if one assigns a value of 1 for $R, K, D$, and $E$ and a value of $\frac{1}{2}$ for $H$. In our model, the CaM is anchored to the connexin by its C-lobe at basal $\left[\mathrm{Ca}^{2+}\right]_{\mathrm{i}}$, while the N-lobe is free to interact with the channel mouth of the mutant's hemichannel.

\subsubsection{CaM-Cork Gating of Homotypic Cx32 Channels Can Be Activated by Large Vj Pulses}

The effect of large $\mathrm{Vj}$ gradients on the $\mathrm{Gj}$ in homotypic Cx32 channels [124], suggests that the gating particle (CaM's N-lobe) can plug the mouth (vestibule) of the hemichannel at the negative $\mathrm{Vj}$ side even in the absence of $\mathrm{Cx}$ mutations or $\left[\mathrm{Ca}^{2+}\right]_{i}$ rise (Figure 11). This would suggest that the hemichannel mouth is not totally inaccessible to the CaM's N-lobe, 
such that large $\mathrm{Vj}$ gradients $(100 \mathrm{mV})$ at the negative side of $\mathrm{Vj}$ can force the $\mathrm{N}$-lobe to access the mouth of the channel. Incidentally, these data also confirm earlier evidence for the $\mathrm{Vj}$ sensitivity of the chemical gate (the negatively charged CaM's N-lobe) $[69,114]$.

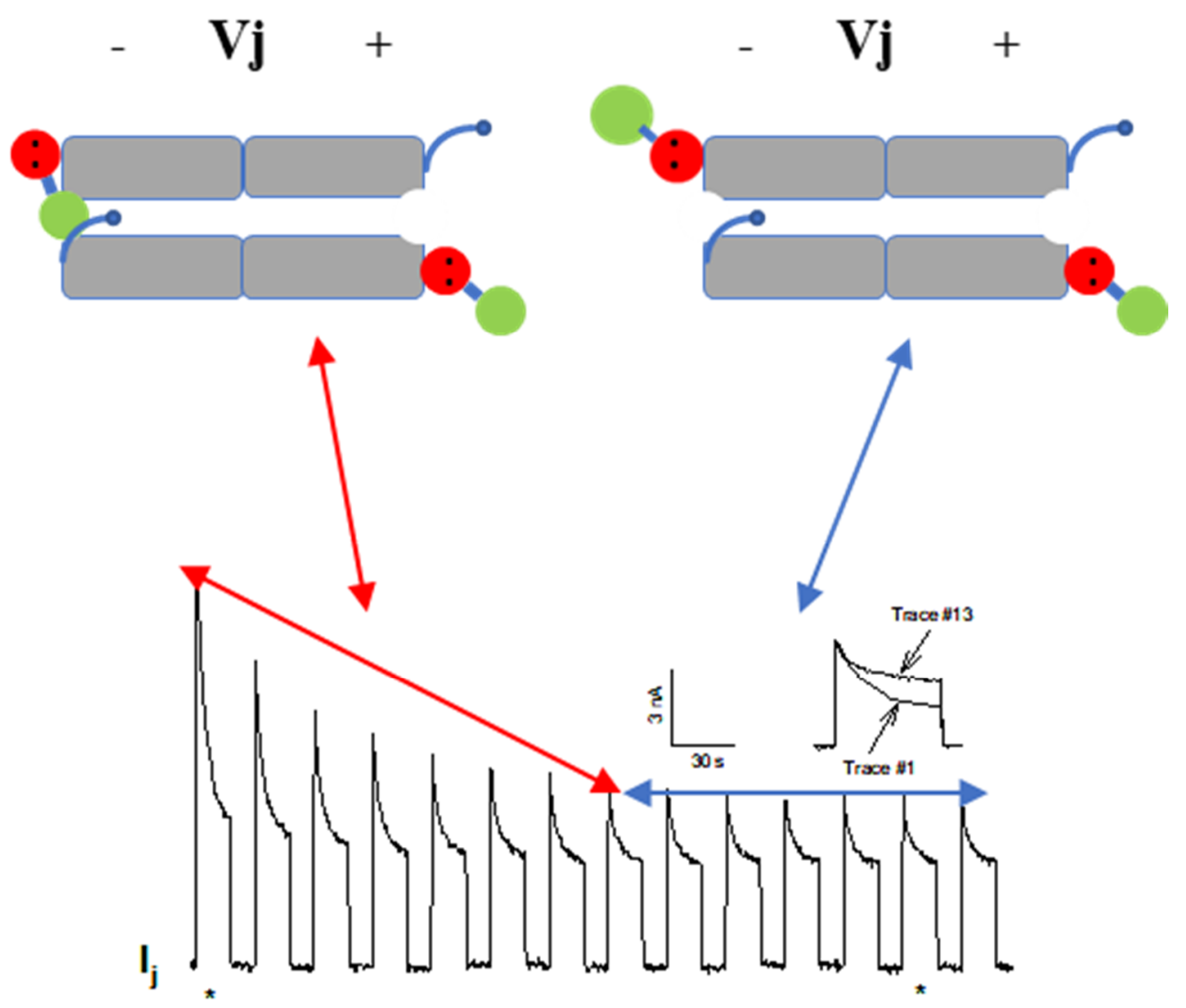

Figure 11. Gj slowly decays in oocytes expressing Cx32 subjected to long $-100 \mathrm{mV}$ Vj pulses. Note the progressive drop in Ij-Peak and, to a lesser extent, Ij-Steady-State. Gj peak drops exponentially by $50-60 \%$, eventually reaching steady state. The large drop in Ij during the first 8 pulses is likely to result from the closure of both chemical/slow gate and fast Vj gate (double-headed red arrow). The Ij behavior of the following $6 \mathrm{Vj}$ pulses is likely to reflect the closure of only the fast $\mathrm{Vj}$ gate of the remaining open channels (double-headed blue arrow). The CaM molecules are labelled in red and green colors to identify $\mathrm{C}$-lobe and $\mathrm{N}$-lobe, respectively. The inset shows a comparison of the time course of $\mathrm{I}_{\mathrm{j}}$ seen in traces \#1 and \#13 (the asterisks below the main tracing indicate their location). Adapted from ref. [124].

\subsubsection{CaM-Cork Gating in Homotypic Cx45 Channels}

In some connexins, large $\mathrm{Vj}$ gradients may not be needed to force the gating element $\left(C a M ' s\right.$ N-lobe) into the channel's mouth at resting $\left[\mathrm{Ca}^{2+}\right]_{\mathrm{i}}$. This may be the case in the Cx45 channels as many Cx45 channels are thought to be closed by the chemical/slow gate even at $\mathrm{Vj}=0$ and without treatments with chemical uncouplers [70,131]. Perhaps, in contrast to the $\mathrm{C} \times 32$ channels, in the $\mathrm{C} \times 45$ channels the positively-charged ring of the channel's mouth is conformed in a way that it is spontaneously accessible to the gating element (CaM's N-lobe) even in the absence of $\mathrm{Vj}$.

\subsubsection{How Many CaM's Lobes Are Needed to Close a Channel?}

With a $\left[\mathrm{Ca}^{2+}\right]_{\mathrm{i}}$ rise sufficient to activate the $\mathrm{N}$-lobe of the CaM, how many $\mathrm{N}$-lobes are expected to participate in the channel gating? If indeed the CaM is anchored to each of the six connexins of a connexon, could all of the six N-lobes simultaneously interact with their receptor for gating the channel? This might be possible, but we think it is unlikely due to 
steric hindrance and because the negatively charged CaM's N-lobes would electrostatically repel each other. More reasonable, in contrast, is the possibility that channel gating is caused by the interaction of just one N-lobe with the receptor site, either in the same connexin (trans-domain interaction) or in another connexin (trans-subunit interaction) of the connexon (Figure 12).

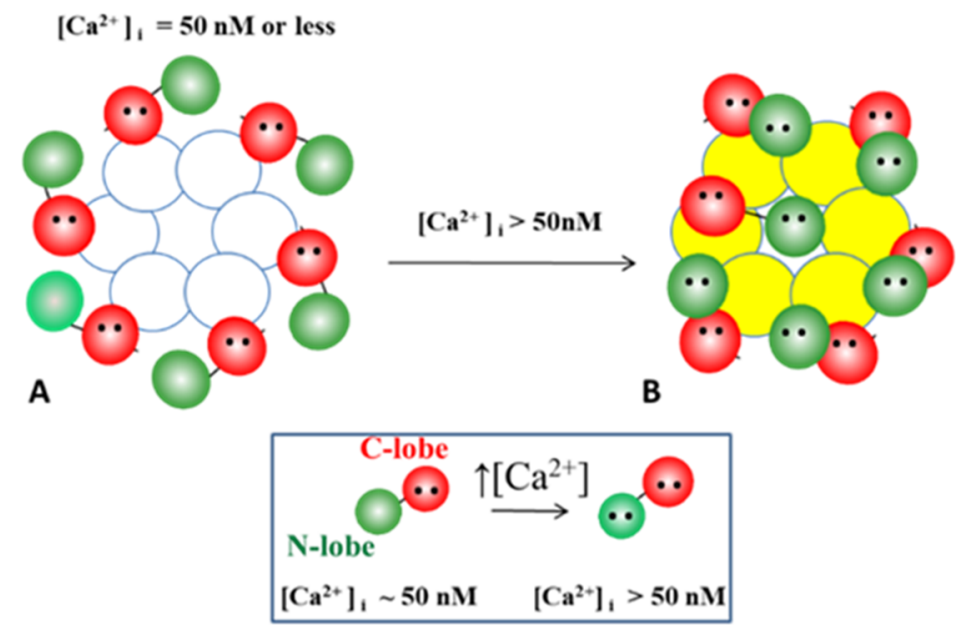

Figure 12. On the basis of the Ca-CaM-Cork model, at normal $\left[\mathrm{Ca}^{2+}\right]_{\mathrm{i}}(\sim 50 \mathrm{nM}) \mathrm{CaM}$ is linked by the C-lobe to each connexin forming a hemichannel (A). With a $\left[\mathrm{Ca}^{2+}\right]_{i}$ rise, the $\mathrm{N}$-lobe plugs the pore. Although all of the six CaM N-lobes could theoretically simultaneously bind to their receptor and gate the channel, this seems unlikely because of steric hindrance. It is more likely that just one of the six $\mathrm{N}$-lobes binds to its receptor site (B). If so, the first $\mathrm{Ca}^{2+}$-activated CaM-lobe wins the competition (first come, first served) and prevents other N-lobes from accessing the mouth of the channel.

It is likely that when $\left[\mathrm{Ca}^{2+}\right]_{i}$ rises near the connexon, the first $\mathrm{N}$-lobe that is activated accesses the channel's mouth, preventing the access of the other N-lobes. Perhaps, the gating N-lobe fluctuates in and out of the channel's mouth or takes turns with another $\mathrm{N}$-lobe before stably gating the channel. Indeed, while studying, by dual cell clamp, the chemical/slow gating of single Cx43 channels, we reported examples of fluctuating transitions from open to closed states and vice-versa [123]. It is possible that the fluctuating transitions reflect the momentary enter-exit activity of individual N-lobes. This is also consistent with the idea that the gate consists of a relatively large particle (CaM's N-lobe).

\subsection{Ca-CaM-Locked-Gate-Irreversible Channel Gating}

There is evidence that in some cases the chemical gating of gap junction channels becomes irreversible [42]. $\mathrm{Xu}$ and coworkers tested the $\mathrm{Ca}^{2+}$-induced uncoupling of $\mathrm{N} 2 \mathrm{a}$ cell pairs expressing $\mathrm{Cx} 43$ treated with $1 \mu \mathrm{M}$ ionomycin in $1.8 \mathrm{mM}\left[\mathrm{Ca}^{2+}\right]_{\mathrm{o}}$ [42]. The Gj drop caused by the ionomycin treatment was prevented by the calmidazolium or competitive peptides. To test the gating reversibility, at the end of the ionomycin treatment the cells were exposed to a no-Ca ${ }^{2+}$-added solution containing $10 \mathrm{mM}$ EGTA. Significantly, if the switch to the no-Ca ${ }^{2+}$-EGTA occurred when the $\mathrm{Gj}$ had only dropped by $50 \%$, the Gj fully recovered, whereas if the switch occurred when the $\mathrm{Gj}$ had dropped to $0 \%$, the $\mathrm{Gj}$ only recovered to $\sim 60 \%$, suggesting that $\sim 1 / 2$ of the channel population remained irreversibly closed. This indicated that two types of gating state may exist: one reversible and the other irreversible-closed-gate and locked-gate, respectively.

\subsubsection{Gap Junction Crystallization and the Locked-Gate Model}

Evidence for an irreversible "locked-gate" state [42] brought to mind our early studies in which were reported changes in gap junction channel aggregation from loose to tight crystalline (hexagonal) arrays, both in invertebrate (Figure 13) and in mammalian (Figure 14) cells, subjected to treatments that uncoupled the cells by increasing 
$\left[\mathrm{Ca}^{2+}\right]_{\mathrm{i}}[17,18,62,127-130,132]$. We interpreted these data to reflect a switch from an opento a closed-channel state.

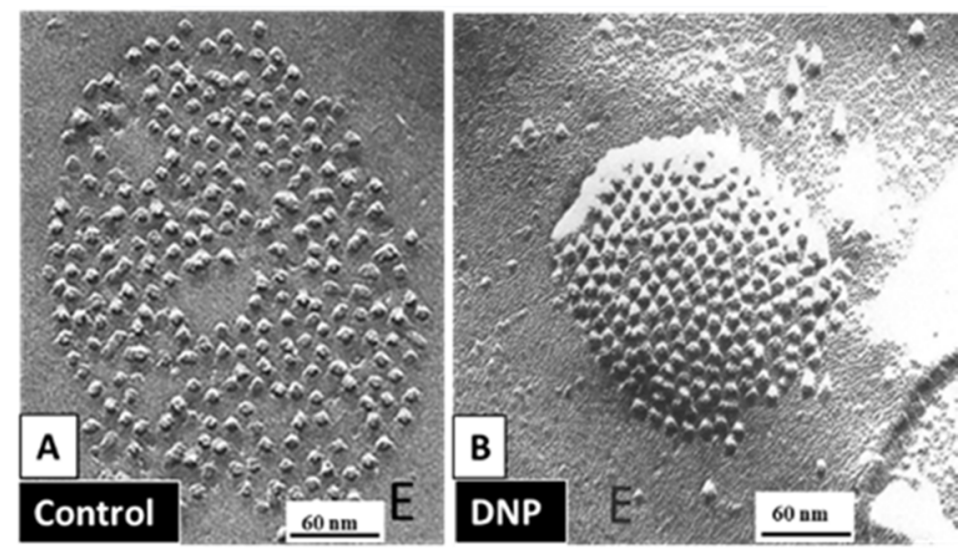

Figure 13. Freeze-fractured gap junctions (E face) of crayfish lateral giant axons fixed in coupled (A) or uncoupled (B) conditions. Uncoupling was caused by treatment with the metabolic inhibitor dinitrophenol (DNP). With DNP treatment, the channels' arrays switched from loose (A) to tightly (hexagonal) packings (B), as the center-to-center spacing between channels decreased from $\sim 200 \AA$ (A) to $<170 \AA$ A (B). Adapted from ref. [128].

\section{Gap junctions of rat stomach uncopled by exposure to the Ca-ionophore A23187}

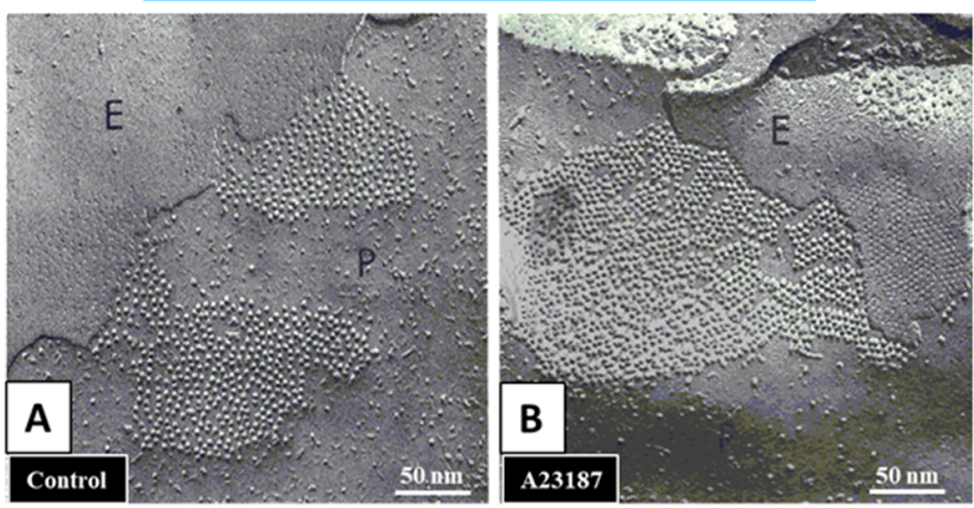

Figure 14. Freeze fractures of rat stomach gap junctions. In samples fixed immediately or kept for 1 $\mathrm{h}$ in an oxygenated saline at $37^{\circ} \mathrm{C}$ the gap junctions show channels irregularly arranged at centerto-center spacings of 103-105 $\AA$ (A). In contrast, in samples kept in salines containing $2 \mu \mathrm{M}$ A23187 $\left(\mathrm{Ca}^{2+}\right.$-ionophore), the channels pack into crystalline, hexagonal arrays with average center-to-center spacings of $\sim 85 \AA$ (B). Adapted from ref. [18].

This interpretation was based on our earlier observation that gap junctions isolated from crayfish nerve cords and stained negatively with phosphotungstic acid (PTA) display tightly packed (hexagonal) arrays with $\sim 150 \AA$ A center-to-center spacings [130] (Figure 15), which are the same as those of the gap junctions of axons fixed in an uncoupled state [128] (Figure 15). Crystalline (hexagonal) arrays were also observed in negatively stained gap junctions isolated from rat liver epithelia (Figure 16) [11]. Thus, we proposed that the channels of the isolated gap junction were in a closed state. We felt that gap junction crystallization is likely to reflect an irreversible state of channel gating (locked-gate state). In support of the gated state of isolated gap junctions in the crystalline state is crystallographic evidence demonstrating that the channels are blocked at both ends by a particle [120-122], which, significantly, is very similar in size to a CaM lobe (see in the following). 


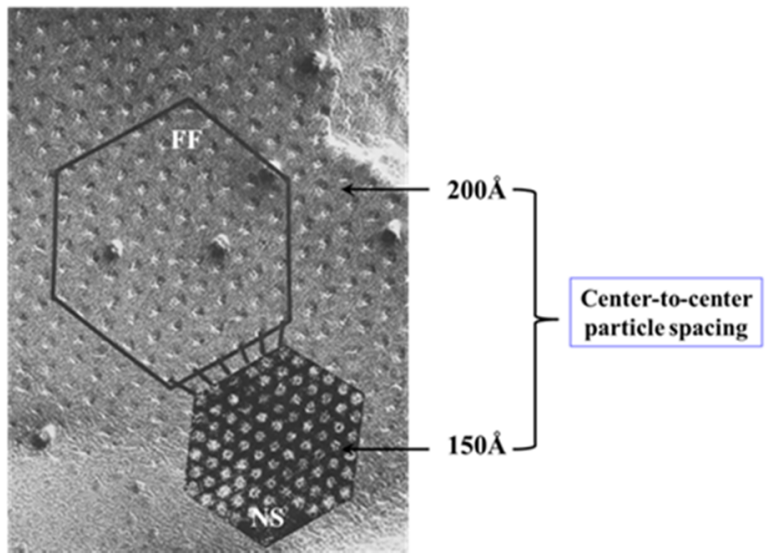

Figure 15. Gap junctions of crayfish lateral giant axons seen in freeze fracture (FF) and in negatively stained isolated junction fragment (NS). In gap junctions fixed in coupled conditions the channels are packed in loose arrays at $\sim 200 \AA$ center-to-center spacing (FF). In contrast, in isolated, negatively stained samples the channels are tightly packed in tight crystalline, hexagonal arrays at 150-170 center-to-center spacing (NS), as in axons exposed to treatments known to increase $\left[\mathrm{Ca}^{2+}\right]_{\mathrm{i}}$ (see Figure 13B). We interpreted these changes to reflect a switch from open- to closed-channel state. We believe that gap junction crystallization represents an irreversible "locked-gate" gating state. Adapted from ref. [128].

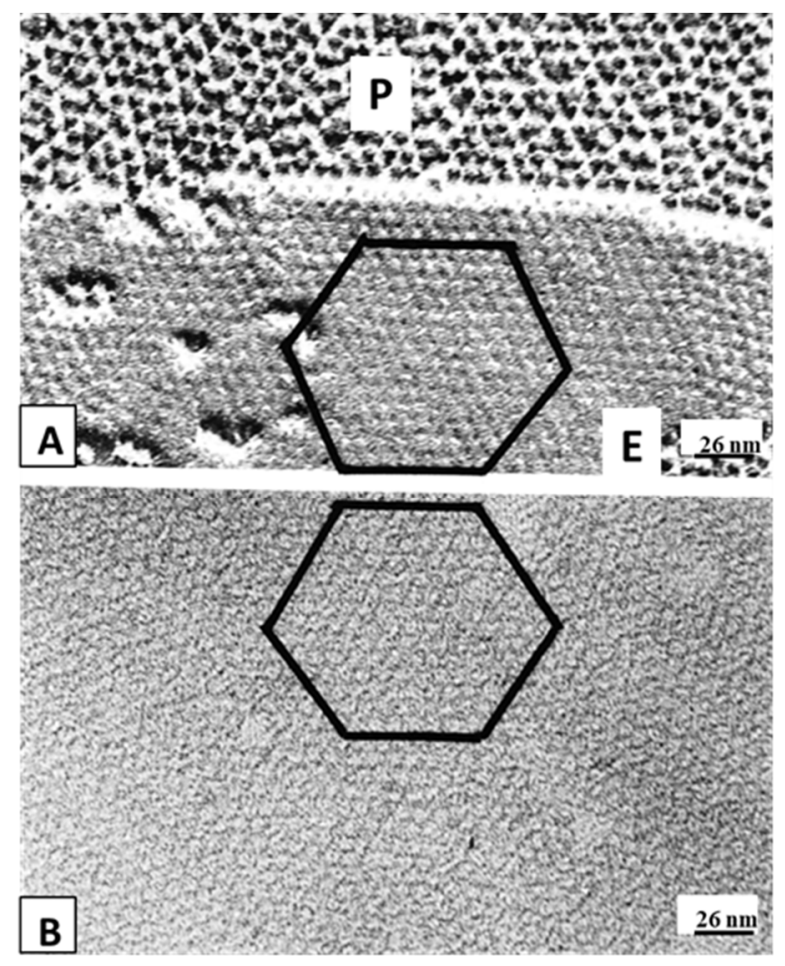

Figure 16. Gap junctions of rat liver epithelium (in uncoupled state) from a freeze-fracture replica (A) and an isolated, negatively stained junction (B). Isolated junctions (B) display crystalline (hexagonal) arrays identical to those of uncoupled junctions (A). The channels of both gap junctions are believed to be in irreversibly closed state (Ca-CaM locked state). In both junctions, the channels are hexagonally packed at an average center-to-center spacing of $-8.5 \mathrm{~nm}$. Adapted from ref. [129].

\subsubsection{What Causes Gap Junction Crystallization?}

Our hypothesis proposes that that the loose, less ordered particle array of coupled junctions is caused by the presence of CaM molecules linked to each of the six connexin of the hemichannel (Figure 17A). We think that in coupled junctions a CaM molecule is 
bound to each connexin by the C-lobe, while the N-lobe is free, such that there would be six unbound CaM N-lobes per hemichannel (Figure 17A). Due to the negative charge of the CaM lobes, the N-lobes would be repelling each other, such that the channels would be separated (Figures 13A and 14A). In coupled junctions, the channels would be spaced at a $\sim 100 \AA$ center-to-center distance in vertebrates and a $\sim 200 \AA$ in crayfish axons, and the junctions would display loose and irregular channel arrays. Based on the Ca-CaM-cork model, moderate $\left[\mathrm{Ca}^{2+}\right]_{\mathrm{i}}$ rise would cause a CaM's N-lobe to reversibly close the channel (Figure 17B). This type of "reversible" gating state (Ca-CaM-cork) would not cause gap junction crystallization, as the electrostatic repulsion among the other five N-lobes would prevent it. So, what is causing gap junction crystallization?

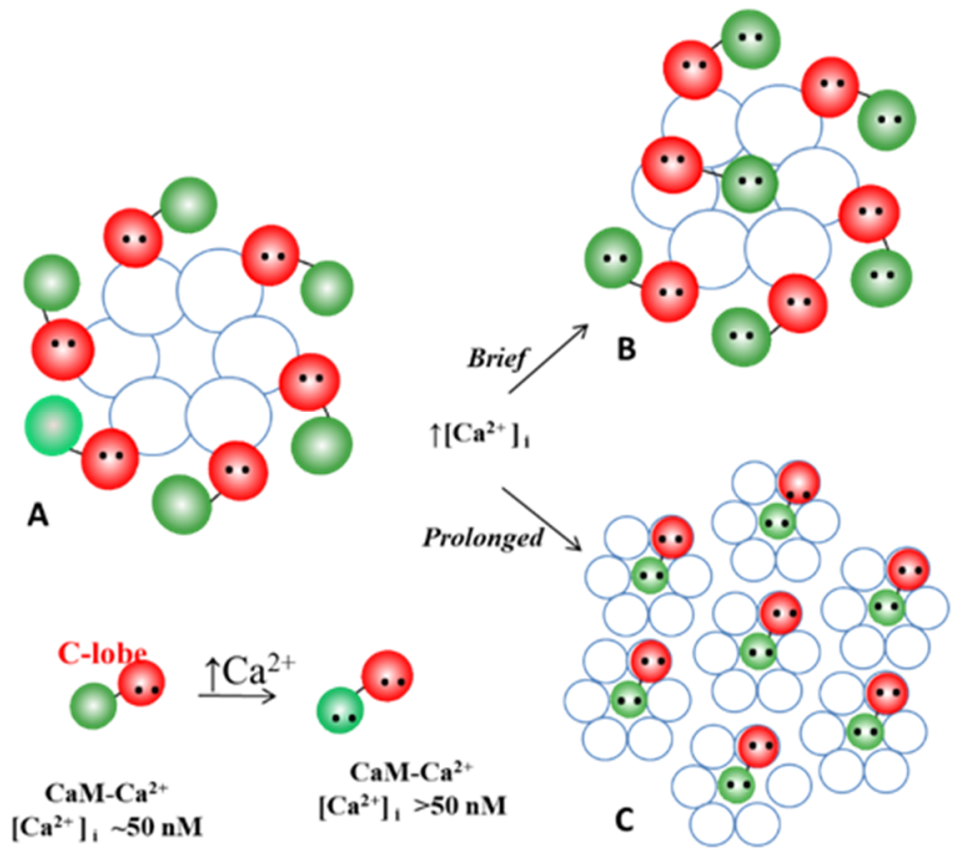

Figure 17. We are proposing that with exposure to high $\left[\mathrm{Ca}^{2+}\right]_{i}$, non-gating CaM molecules, bound to connexins by one lobe (B), detach from connexins $(\mathbf{C})$, enabling the channels to become tightly arranged into crystalline arrays $(\mathbf{C})$, interacting mostly hydrophobically with each other. (A) Permeable channel. (B) Channel reversibly gated. (C) Irreversibly closed channel ("lock-gated").

Our idea is that with prolonged exposure to high $\left[\mathrm{Ca}^{2+}\right]_{\mathrm{i}}$ all but one CaM molecule may detach from the connexins (Figure 17C). This would eliminate the repulsive force among channels, causing the channels to tightly aggregate into crystalline (hexagonal) arrays (Figures 13-16 and Figure 17C) and interact with each other mostly hydrophobically. This could be the reason why during the process of gap junction isolation the channels remain tightly linked to each other (Figures 15 and 16B).

If this were the case, what would cause the release of CaM molecules from gap junctions at high $\left[\mathrm{Ca}^{2+}\right]_{\mathrm{i}}$ ? Black and coworkers [133] invented a fluorescent biosensor designed for determining $[\mathrm{CaM}]_{\mathrm{i}}$ of both $\mathrm{Ca}^{2+}{ }^{2}$ free (apo-CaM) and $\mathrm{Ca}^{2+}$-activated (holo-CaM). In a human kidney cell line, they found that the $[\mathrm{CaM}]_{\mathrm{i}}$ at basal $\left[\mathrm{Ca}^{2+}\right]_{\mathrm{i}}$ is $8.8 \pm 2.2 \mu \mathrm{M}$, but a $\left[\mathrm{Ca}^{2+}\right]_{\mathrm{i}}$ increase dramatically decreases the $[\mathrm{CaM}]_{\mathrm{i}}$ to $\leq 200 \mathrm{nM}$ because of the extensive buffering of the free CaM by the large increase in the available CaM-binding sites. The same phenomenon with $\left[\mathrm{Ca}^{2+}\right]_{I}$ elevation was observed in rabbit cardiac-myocytes, as the CaM reversibly migrated into the nucleus [134]; this study also reported that with a $\left[\mathrm{Ca}^{2+}\right]_{\mathrm{i}}$ rise, the $\mathrm{CaM}$ migrates from the $\mathrm{Z}$-line to the $\mathrm{Ca}^{2+}-\mathrm{CaM}$-binding sites with higher affinity. The same phenomenon may to occur in gap junctions, a possibility being that with a great increase in $\left[\mathrm{Ca}^{2+}\right]_{\mathrm{i}}$ the non-gating CaM molecules, linked to the connexins by just one lobe, are released from the connexins. 
We are aware that the mechanism for gap junction crystallization we are proposing is highly speculative and needs to be experimentally tested. Perhaps, future work could test this idea by attempting to detect biochemically the presence of CaM molecule in isolated gap junctions. However, one should realize that if only two CaM molecules are bound to each channel of crystalline gap junction fragments, the CaM will only represent $14.3 \%$ of the proteins, as each channel is made of twelve connexin monomers.

\section{The Calmodulin-Cork Model Is Supported by X-ray Diffraction Images of Isolated Gap Junction Channels in Closed State}

In the early 1980s, Makowski and coworkers described the structure of crystalline (hexagonal) gap junctions isolated from mouse liver in a high-resistance configuration (closed channels) by analyzing X-ray diffraction data at $18 \AA$ resolution (Figures 18 and 19B) [120,121]. The channels' gated condition of these isolated gap junctions was proven by the evidence that the channels were impermeable to sucrose [120]; in their words: "Analysis of diffraction patterns from isolated gap junctions in 50\% sucrose shows that the sucrose fills the extracellular gap but fails to enter the channel. It is possible that the channel is closed at both cytoplasmic surfaces, excluding sucrose. This suggests that the isolated junctions are in a high resistance state" [120]. Indeed, the three-dimensional map of the electron density demonstrated that the channels were blocked at both cytoplasmic ends by a small particle; in their words: "Its position blocking the channel suggests that it may comprise a gating structure responsible for the control of channel permeability, X-ray diffraction studies of junctions in varying concentrations of sucrose (Makowski et al. 1984a) [122] indicated that in these preparations the channel was closed to the penetration of sucrose and that a solvent region approximately $100 \AA$ long and centered on the six fold axis remained free of sucrose" [121].

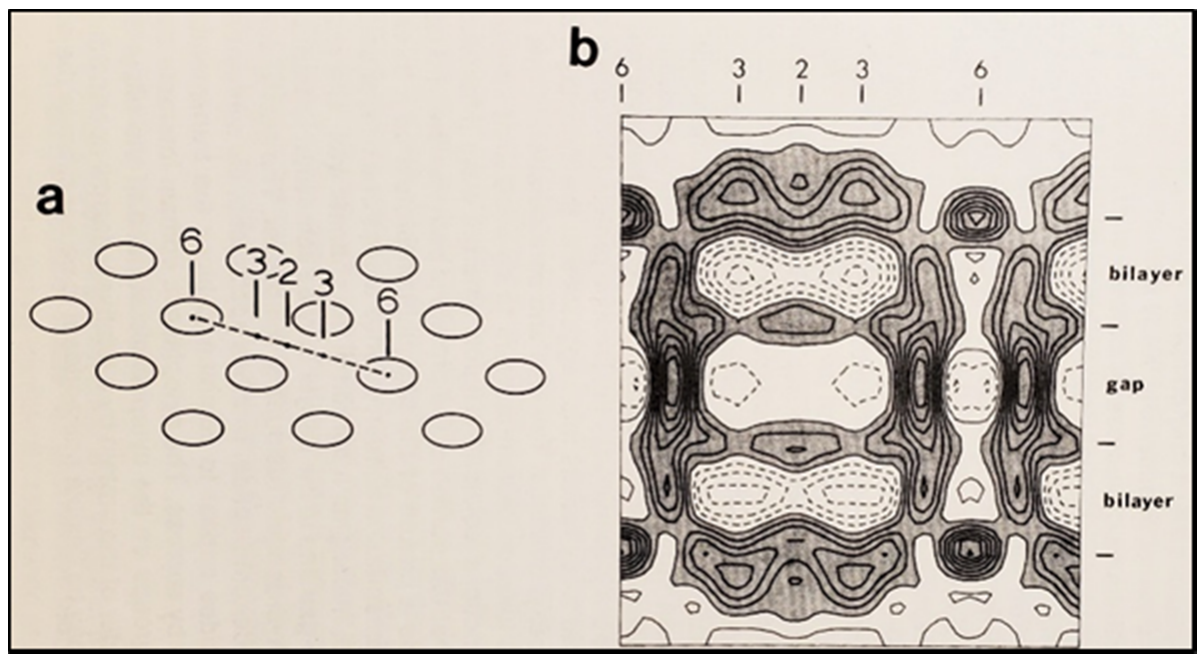

Figure 18. Diagram of the three-dimensional structure of a frozen-hydrated gap junction isolated from mouse liver and solved to $18 \AA$ resolution by X-ray diffraction. The channel " 6 " in $(\mathbf{a}, \mathbf{b})$ is impermeable to $50 \%$ sucrose, proving that it is closed at each cytoplasmic end by a particle that prevents sucrose entry. This proves that the channels of isolated (crystalline) junctions are in closed state (Ca-CaM locked state). Reproduced from ref. [121] with permission from the Journal of Molecular Biology and the Cold Spring Harbor Laboratories. 


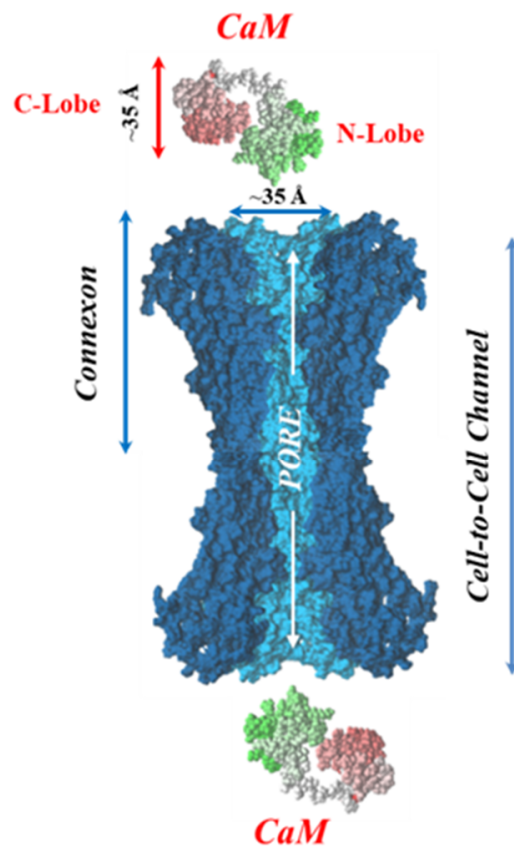

A

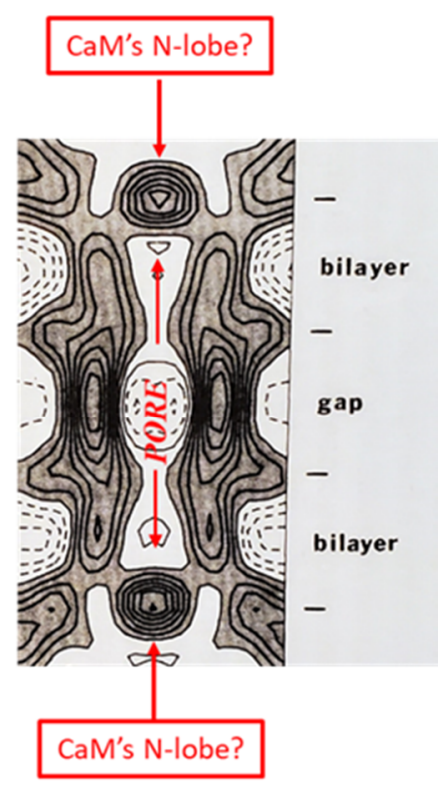

B

Figure 19. Both the positively charged channel's mouth and the negatively charged CaM lobes are $\sim 35 \AA$ in size (A). Thus, a CaM lobe could fit well within the positively charged connexon's mouth (A). Significantly, the three-dimensional structure of gap junctions isolated from mouse liver (B) demonstrates that the channel of isolated (crystalline) junctions is impermeable to $50 \%$ sucrose, proving that it is closed at each cytoplasmic end by a particle that prevents sucrose entry (B). Our hypothesis is that the blocking particle is the CaM's N-lobe (B). Both the CaM and connexon images (A) were provided by Dr. Francesco Zonta (VIMM, University of Padua, Italy. (B) was reproduced from ref. [121] with permission from the Journal of Molecular Biology and the Cold Spring Harbor Laboratories.

Significantly, the blocking particle, spherical in shape, is approximately $30-35 \AA$ in diameter [121] (Figures 18 and 19B), which is remarkably similar in size to a CaM lobe (Figure 19A). Indeed, in their words: “The channel has a diameter of 20-30 A along most of its length but appears to narrow to a minimum diameter of about $15 \AA$ in the extracellular half of the bilayer. Both the sucrose results and the three-dimensional map are consistent with the idea that a structure located near the cytoplasmic surface of the membraned is blocking the channel in these preparations" [121]. These studies support our evidence that gap junctions with crystalline (hexagonal) channel arrays are in an uncoupled (gated) state (Ca-CaM locked gate, Figures 13-16) $[11,17,18,127-130]$ and suggest that a CaM lobe is gating the channel.

\section{Conclusions and Future Perspectives}

This article has reviewed four decades of data supporting the direct role of CaM in gap junction channel gating. The Ca-CaM-cork gating mechanism [113], proposed over two decades ago [112], is based on evidence from the effect of CaM inhibitors, the inhibition of $\mathrm{CaM}$ expression, the expression of a CaM mutant (CaMCC) with higher $\mathrm{Ca}^{2+}$-sensitivity, CaM-connexin co-localization at gap junctions, the presence of high-affinity CaM-binding sites in connexins, the expression of connexin mutants, the gating effect of repeated large $\mathrm{Vj}$ pulses, data at the single channel level, the recovery of lost gating competency by addition of Ca-CaM to internally perfused crayfish axons and, finally, X-ray diffraction data on isolated gap junction fragments.

One may ask: why is it important to understand in detail the gating mechanism of gap junction channels? It is important not only because cell-cell uncoupling is more than 
just a safety mechanism for protecting healthy cells from damaged neighbors (healing over), but because the gating sensitivity to $\left[\mathrm{Ca}^{2+}\right]_{\mathrm{i}}$ in the high nanomolar range indicates that the fine modulation of direct cell-cell communication provides cells with the means for regulating tissue homeostasis. In addition, and more importantly, the field should be encouraged to test the effect of recently discovered disease-causing CaM mutants on gap junction function [135].

Indeed, recent evidence of diseases caused by CaM mutations [136-141] suggests the potential role of CaM mutants in diseases affecting gap junction function. Almost two dozen CaM mutations have been found to cause cardiac malfunctions, most of which occur in the CaM's C-lobe, one in the N-lobe, and one in the linker between the C-and N-lobes. In most cases the electrocardiogram (ECG) demonstrates the presence of Long QT Syndrome (LQTS), a change that affects the electrical activity of the heart, which is often associated with Catecholaminergic Polymorphic Ventricular Tachycardia (CPVT) phenotype and Idiopathic Ventricular Fibrillation (IVF). CPVT patients manifest ventricular tachycardia that can lead to death by ventricular fibrillation. In most cases, cardiac malfunctions have been attributed to the effect of CaM mutations on the ryanodine receptor (RyR2) and the cardiac L-type voltage-gated $\mathrm{Ca}^{2+}$ channel. However, other membrane channels, potential targets of CaM mutants, have also been suggested. Curiously, however, in spite of strong evidence for the direct $\mathrm{CaM}$ role in gap junction channel regulation, the potential consequences of these $\mathrm{CaM}$ mutants on direct cell-cell communication-a mechanism fundamental for the function of virtually all vertebrate and invertebrate organs-have not yet been addressed. Therefore, it is clear that future efforts should be aimed at testing the effect of these CaM mutants, and the future discovered CaM mutants, on gap junction mediated communication [135].

Author Contributions: C.P. is the principal investigator. L.M.L.P., Research Assistant, has performed the general lab work and the technical work for preparation and injection of oocytes. All authors have read and agreed to the published version of the manuscript.

Funding: This research received no external funding.

Conflicts of Interest: The authors declare no conflict of interest.

\section{References}

1. Stough, H.B. Giant nerve fibers of the earthworn. J. Comp. Neurol. 1926, 40, 409-463. [CrossRef]

2. Stough, H.B. Polarization of the giant nerve fibers of the earthworm. J. Comp. Neurol. 1930, 50, 217-229. [CrossRef]

3. Weidmann, S. The electrical constants of Purkinje fibres. J. Physiol. 1952, 118, 348-360. [CrossRef] [PubMed]

4. Kanno, Y.; Loewenstein, W.R. Low-resistance coupling between gland cells. Some observations on intercellular contact membranes and intercellular space. Nature 1964, 201, 194-195. [CrossRef]

5. Loewenstein, W.R.; Kanno, Y. Studies on an epithelial (gland) cell junction. i. modifications of surface membrane permeability. J. Cell Biol. 1964, 22, 565-586. [CrossRef]

6. Kuffler, S.W.; Potter, D.D. Glia in the leech central nervous system: Physiological properties and neuron-glia relationship. J. Neurophysiol. 1964, 27, 290-320. [CrossRef]

7. Rothschuh, K.E. Über den aufbau des herzmuskels aus “elektrophysiologischen elementen". Verh. Der Dtsch. Ges. Fur Kreislaufforsch. 1950, 16, 226-232.

8. Rothschuh, K.E. Über den funktionellen aufbaudes herzens aus elektrophysiologischen Elementen und üiber den mechanismus der erregungsleitung im herzen. Pflüg. Arch. 1951, 253, 238-251. [CrossRef]

9. De Mello, W.C.; Motta, G.E.; Chapeau, M. A study on the healing-over of myocardial cells of toads. Circ. Res. 1969, 24, 475-487. [CrossRef]

10. Engelmann, T.W. Vergleichende Untersuchungen zur Lehre von der Muskel und Nervenelektricität. Pflügers Arch. 1877, 15, 116-148. [CrossRef]

11. Peracchia, C. Structural correlates of gap junction permeation. Int. Rev. Cytol. 1980, 66, 81-146.

12. Peracchia, C. Cell coupling. In Membrane Structure and Dynamics; Martonosi, A.N., Ed.; Plenum Press: New York, NY, USA, 1985; pp. 81-130.

13. Rose, B.; Loewenstein, W.R. Permeability of cell junction depends on local cytoplasmic calcium activity. Nature 1975, 254, 250-252. [CrossRef]

14. Loewenstein, W.R. Junctional intercellular communication: The cell-to-cell membrane channel. Physiol. Rev. 1981, 61, 829-913. [CrossRef] 
15. Bennett, M.V.L. Junctional permeability. In Intercellular Junctions and Synapses; Feldman, J., Gilula, N.B., Pitts, J.D., Eds.; John Wiley and Sons: New York, NY, USA, 1978; pp. 25-36.

16. Délèze, J. Calcium ions and the healing over of heart fibers. In Electrophysiology of the Heart; Taccardi, B., Marchetti, C., Eds.; Pergamon Press: Oxford, UK, 1965; pp. 147-148.

17. Peracchia, C. Calcium effects on gap junction structure and cell coupling. Nature 1978, 271, 669-671. [CrossRef]

18. Peracchia, C.; Peracchia, L.L. Gap junction dynamics: Reversible effects of divalent cations. J. Cell Biol. 1980, 87, 708-718. [CrossRef]

19. Peracchia, C. Chemical gating of gap junction channels; roles of calcium, $\mathrm{pH}$ and calmodulin. Biochim. Biophys. Acta (BBA)Biomembr. 2004, 1662, 61-80. [CrossRef]

20. De Mello, W.C. Influence of the sodium pump on intercellular communication in heart fibres: Effect of intracellular injection of sodium ion on electrical coupling. J. Physiol. 1976, 263, 171-197. [CrossRef]

21. Loewenstein, W.R. Permeable junctions. Cold Spring Harb. Symp. Quant. Biol. 1975, 40, 49-63. [CrossRef]

22. Rose, B.; Loewenstein, W.R. Permeability of a cell junction and the local cytoplasmic free ionized calcium concentration: A study with aequorin. J. Membr. Biol. 1976, 28, 87-119. [CrossRef]

23. Délèze, J.; Loewenstein, W.R. Permeability of a cell junction during intracellular injection of divalent cations. J. Membr. Biol. 1976, 28, 71-86. [CrossRef]

24. De Mello, W.C. Effect of intracellular injection of calcium and strontium on cell communication in heart. J. Physiol. 1975, 250, 231-245. [CrossRef]

25. Bernardini, G.; Peracchia, C.; Venosa, R.A. Healing-over in rat crystalline lens. J. Physiol. 1981, 320, 187-192. [CrossRef]

26. Oliveira-Castro, G.M.; Loewenstein, W.R. Junctional membrane permeability: Effects of divalent cations. J. Membr. Biol. 1971, 5, 51-77. [CrossRef]

27. Spray, D.C.; Stern, J.H.; Harris, A.L.; Bennett, M.V. Gap junctional conductance: Comparison of sensitivities to H and Ca ions. Proc. Natl. Acad. Sci. USA 1982, 79, 441-445. [CrossRef]

28. Noma, A.; Tsuboi, N. Dependence of junctional conductance on proton, calcium and magnesium ions in cardiac paired cells of guinea-pig. J. Physiol. 1987, 382, 193-211. [CrossRef]

29. Noma, A.; Tsuboi, N. Direct measurement of the gap junctional conductance under the influence of Ca2+ in dissociated paired myocytes of guinea-pig. Jpn. Heart J. 1986, 27 (Suppl. 1), 161-166.

30. Dekker, L.R.; Fiolet, J.W.; VanBavel, E.; Coronel, R.; Opthof, T.; Spaan, J.A.; Janse, M.J. Intracellular Ca2+, intercellular electrical coupling, and mechanical activity in ischemic rabbit papillary muscle. Effects of preconditioning and metabolic blockade. Circ. Res. 1996, 79, 237-246. [CrossRef]

31. Peracchia, C. Effects of caffeine and ryanodine on low pHi-induced changes in gap junction conductance and calcium concentration in crayfish septate axons. J. Membr. Biol. 1990, 117, 79-89. [CrossRef]

32. Peracchia, C. Increase in gap junction resistance with acidification in crayfish septate axons is closely related to changes in intracellular calcium but not hydrogen ion concentration. J. Membr. Biol. 1990, 113, 75-92. [CrossRef]

33. Neyton, J.; Trautmann, A. Single-channel currents of an intercellular junction. Nature 1985, 317, 331-335. [CrossRef]

34. Lazrak, A.; Peracchia, C. Gap junction gating sensitivity to physiological internal calcium regardless of $\mathrm{pH}$ in Novikoff hepatoma cells. Biophys. J. 1993, 65, 2002-2012. [CrossRef]

35. Lazrak, A.; Peres, A.; Giovannardi, S.; Peracchia, C. Ca-mediated and independent effects of arachidonic acid on gap junctions and Ca-independent effects of oleic acid and halothane. Biophys. J. 1994, 67, 1052-1059. [CrossRef]

36. Enkvist, M.O.; McCarthy, K.D. Astroglial gap junction communication is increased by treatment with either glutamate or high $\mathrm{K}^{+}$ concentration. J. Neurochem. 1994, 62, 489-495. [CrossRef] [PubMed]

37. Cotrina, M.L.; Kang, J.; Lin, J.H.; Bueno, E.; Hansen, T.W.; He, L.; Liu, Y.; Nedergaard, M. Astrocytic gap junctions remain open during ischemic conditions. J. Neurosci. 1998, 18, 2520-2537. [CrossRef]

38. Giaume, C.; Venance, L. Characterization and regulation of gap junction channels in cultured astrocytes. In Gap Junctions in the Nervous System; Spray, D.C., Dermietzel, R., Eds.; R.G Landes Medical Pub.: Austin, TX, USA, 1996; pp. 135-157.

39. Crow, J.M.; Atkinson, M.M.; Johnson, R.G. Micromolar levels of intracellular calcium reduce gap junctional permeability in lens cultures. Investig. Ophthalmol. Vis. Sci. 1994, 35, 3332-3341.

40. Mears, D.; Sheppard, N.F., Jr.; Atwater, I.; Rojas, E. Magnitude and modulation of pancreatic beta-cell gap junction electrical conductance in situ. J. Membr. Biol. 1995, 146, 163-176. [CrossRef]

41. Dakin, K.; Zhao, Y.; Li, W.H. LAMP, a new imaging assay of gap junctional communication unveils that Ca2+ influx inhibits cell coupling. Nat. Methods 2005, 2, 55-62. [CrossRef]

42. Xu, Q.; Kopp, R.F.; Chen, Y.; Yang, J.J.; Roe, M.W.; Veenstra, R.D. Gating of connexin 43 gap junctions by a cytoplasmic loop calmodulin binding domain. Am. J. Physiol. Cell Physiol. 2012, 302, C1548-C1556. [CrossRef]

43. Iwatsuki, N.; Petersen, O.H. Membrane potential, resistance, and intercellular communication in the lacrimal gland: Effects of acetylcholine and adrenaline. J. Physiol. 1978, 275, 507-520. [CrossRef]

44. Iwatsuki, N.; Petersen, O.H. Pancreatic acinar cells: Acetylcholine-evoked electrical uncoupling and its ionic dependency. J. Physiol. 1978, 274, 81-96. [CrossRef]

45. Iwatsuki, N.; Petersen, O.H. Electrical coupling and uncoupling of exocrine acinar cells. J. Cell Biol. 1978, 79 Pt 1, 533-545. [CrossRef] 
46. Matthews, E.K.; Petersen, O.H. Pancreatic acinar cells: Ionic dependence of the membrane potential and acetycholine-induced depolarization. J. Physiol. 1973, 231, 283-295. [CrossRef]

47. Scheele, G.A.; Palade, G.E. Studies on the guinea pig pancreas. Parallel discharge of exocrine enzyme activities. J. Biol. Chem. 1975, 250, 2660-2670. [CrossRef]

48. Ochs, D.L.; Korenbrot, J.I.; Williams, J.A. Intracellular free calcium concentrations in isolated pancreatic acini; effects of secretagogues. Biochem. Biophys. Res. Commun. 1983, 117, 122-128. [CrossRef]

49. Lurtz, M.M.; Louis, C.F. Calmodulin and protein kinase C regulate gap junctional coupling in lens epithelial cells. Am. J. Physiol. Cell Physiol. 2003, 285, C1475-C1482. [CrossRef]

50. Peracchia, C. Gap Junction Stucture and Chemical Regulation. Direct Calmodulin Role in Cell-to-Cell Channel Gating; Academic Press: London, UK, 2019.

51. Peracchia, C. Calmodulin-mediated regulation of gap junction channels. Int. J. Mol. Sci. 2020, 21, 485. [CrossRef]

52. Zou, J.; Salarian, M.; Chen, Y.; Veenstra, R.; Louis, C.F.; Yang, J.J. Gap junction regulation by calmodulin. FEBS Lett. 2014, 588, 1430-1438. [CrossRef]

53. Johnston, M.F.; Ramon, F. Electrotonic coupling in internally perfused crayfish segmented axons. J. Physiol. 1981, 317, 509-518. [CrossRef]

54. Arellano, R.O.; Ramon, F.; Rivera, A.; Zampighi, G.A. Calmodulin acts as an intermediary for the effects of calcium on gap junctions from crayfish lateral axons. J. Membr. Biol. 1988, 101, 119-131. [CrossRef]

55. Peracchia, C.; Bernardini, G.; Peracchia, L.L. A calmodulin inhibitor prevents gap junction crystallization and electrical uncoupling. J. Cell Biol. 1981, 91, 124a.

56. Peracchia, C.; Bernardini, G.; Peracchia, L.L. Is calmodulin involved in the regulation of gap junction permeability? Pflug. Arch. 1983, 399, 152-154. [CrossRef]

57. Hertzberg, E.L.; Gilula, N.B. Liver gap junctions and lens fiber junctions: Comparative analysis and calmodulin interaction. Cold Spring Harb. Symp. Quant. Biol. 1981, 46, 639-645. [CrossRef]

58. Van Eldik, L.J.; Hertzberg, E.L.; Berdan, R.C.; Gilula, N.B. Interaction of calmodulin and other calcium-modulated proteins with mammalian and arthropod junctional membrane proteins. Biochem. Biophys. Res. Commun. 1985, 126, 825-832. [CrossRef]

59. Arellano, R.O.; Ramon, F.; Rivera, A.; Zampighi, G.A. Lowering of pH does not directly affect the junctional resistance of crayfish lateral axons. J. Membr. Biol. 1986, 94, 293-299. [CrossRef]

60. Benson, A.M. Identification of Innexins Contributing to the Giant-Fiber Escape Response in Marbled Crayfish. Ph.D. Thesis, Illinois State University, Normal, IL, USA, 2020.

61. Wang, X.G.; Peracchia, C. Positive charges of the initial C-terminus domain of $\mathrm{Cx} 32$ inhibit gap junction gating sensitivity to $\mathrm{CO}_{2}$. Biophys. J. 1997, 73, 798-806. [CrossRef]

62. Peracchia, C.; Bernardini, G. Gap junction structure and cell-to-cell coupling regulation: Is there a calmodulin involvement? Fed. Proc. 1984, 43, 2681-2691.

63. Peracchia, C. Communicating junctions and calmodulin: Inhibition of electrical uncoupling in Xenopus embryo by calmidazolium. J. Membr. Biol. 1984, 81, 49-58. [CrossRef]

64. Peracchia, C. Calmodulin-like proteins and communicating junctions. Electrical uncoupling of crayfish septate axons is inhibited by the calmodulin inhibitor W7 and is not affected by cyclic nucleotides. Pflug. Arch. 1987, 408, 379-385. [CrossRef]

65. Wojtczak, J.A. Electrical uncoupling induced by general anesthetics: A calcium-independent process. In Gap Junctions; Bennett, M.V.L., Spray, D.C., Eds.; Cold Spring Harbor Laboratory: Cold Spring Harbor, NY, USA, 1985; pp. 167-175.

66. Tuganowski, W.; Korczynska, I.; Wasik, K.; Piatek, G. Effects of calmidazolium and dibutyryl cyclic AMP on the longitudinal internal resistance in sinus node strips. Pflug. Arch. 1989, 414, 351-353. [CrossRef]

67. Gandolfi, S.A.; Duncan, G.; Tomlinson, J.; Maraini, G. Mammalian lens inter-fiber resistance is modulated by calcium and calmodulin. Curr. Eye Res. 1990, 9, 533-541. [CrossRef]

68. Peracchia, C.; Wang, X.; Li, L.; Peracchia, L.L. Inhibition of calmodulin expression prevents low-pH-induced gap junction uncoupling in Xenopus oocytes. Pflug. Arch. 1996, 431, 379-387. [CrossRef] [PubMed]

69. Peracchia, C.; Wang, X.G.; Peracchia, L.L. Slow gating of gap junction channels and calmodulin. J. Membr. Biol. 2000, 178, 55-70. [CrossRef] [PubMed]

70. Peracchia, C.; Young, K.C.; Wang, X.G.; Peracchia, L.L. Is the voltage gate of connexins $\mathrm{CO}_{2}$-sensitive? Cx45 channels and inhibition of calmodulin expression. J. Membr. Biol. 2003, 195, 53-62. [CrossRef]

71. Peracchia, C.; Sotkis, A.; Wang, X.G.; Peracchia, L.L.; Persechini, A. Calmodulin directly gates gap junction channels. J. Biol. Chem. 2000, 275, 26220-26224. [CrossRef] [PubMed]

72. Sotkis, A.; Wang, X.G.; Yasumura, T.; Peracchia, L.L.; Persechini, A.; Rash, J.E.; Peracchia, C. Calmodulin colocalizes with connexins and plays a direct role in gap junction channel gating. Cell Commun. Adhes. 2001, 8, 277-281. [CrossRef]

73. Kerruth, S.; Coates, C.; Rezavi, S.A.; Peracchia, C.; Torok, K. Ca ${ }^{2+}$-dependent and -independent interaction of calmodulin with gap junction cytoplasmic loop peptides. 2021; in preparation.

74. Kerruth, S.; Coates, C.; Rezavi, S.A.; Peracchia, C.; Torok, K. Calmodulin interaction with gap junction intracellular loop peptides. Biophys. J. 2018, 114, 468a. [CrossRef]

75. Dodd, R.; Peracchia, C.; Stolady, D.; Torok, K. Calmodulin association with connexin32-derived peptides suggests trans-domain interaction in chemical gating of gap junction channels. J. Biol. Chem. 2008, 283, 26911-26920. [CrossRef] 
76. Torok, K.; Stauffer, K.; Evans, W.H. Connexin 32 of gap junctions contains two cytoplasmic calmodulin-binding domains. Biochem. J. 1997, 326, 479-483. [CrossRef]

77. Zou, J.; Salarian, M.; Chen, Y.; Zhuo, Y.; Brown, N.E.; Hepler, J.R.; Yang, J. Direct Visualization of Interaction between Calmodulin and Connexin45. Biochem. J. 2017, 474, 4035-4051. [CrossRef]

78. Chen, Y.; Zhou, Y.; Lin, X.; Wong, H.C.; Xu, Q.; Jiang, J.; Wang, S.; Lurtz, M.M.; Louis, C.F.; Veenstra, R.D.; et al. Molecular interaction and functional regulation of connexin50 gap junctions by calmodulin. Biochem. J. 2011, 435, 711-722. [CrossRef]

79. Zhou, Y.; Yang, W.; Lurtz, M.M.; Chen, Y.; Jiang, J.; Huang, Y.; Louis, C.F.; Yang, J.J. Calmodulin mediates the Ca2+-dependent regulation of CX44 gap junctions. Biophys. J. 2009, 96, 2832-2848. [CrossRef]

80. Zhou, Y.; Yang, W.; Lurtz, M.M.; Ye, Y.; Huang, Y.; Lee, H.W.; Chen, Y.; Louis, C.F.; Yang, J.J. Identification of the calmodulin binding domain of connexin 43. J. Biol. Chem. 2007, 282, 35005-35017. [CrossRef]

81. Peracchia, C. Direct communication between axons and sheath glial cells in crayfish. Nature 1981, 290, 597-598. [CrossRef]

82. Saimi, Y.; Kung, C. Calmodulin as an ion channel subunit. Annu. Rev. Physiol. 2002, 64, 289-311. [CrossRef]

83. Kovalevskaya, N.V.; van de Waterbeemd, M.; Bokhovchuk, F.M.; Bate, N.; Bindels, R.J.; Hoenderop, J.G.; Vuister, G.W. Structural analysis of calmodulin binding to ion channels demonstrates the role of its plasticity in regulation. Pflug. Arch. 2013, 465, 1507-1519. [CrossRef]

84. Peracchia, C.; Girsch, S.J. Calmodulin site at the C-terminus of the putative lens gap junction protein MIP26. Lens Eye Toxic. Res. 1989, 6, 613-621.

85. Girsch, S.J.; Peracchia, C. Calmodulin interacts with a C-terminus peptide from the lens membrane protein MIP26. Curr. Eye Res. 1991, 10, 839-849. [CrossRef]

86. Nemeth-Cahalan, K.L.; Hall, J.E. pH and calcium regulate the water permeability of aquaporin 0. J. Biol. Chem. 2000, 275, 6777-6782. [CrossRef]

87. Nemeth-Cahalan, K.L.; Kalman, K.; Hall, J.E. Molecular basis of pH and Ca2+ regulation of aquaporin water permeability. J. Gen. Physiol. 2004, 123, 573-580. [CrossRef]

88. Reichow, S.L.; Clemens, D.M.; Freites, J.A.; Nemeth-Cahalan, K.L.; Heyden, M.; Tobias, D.J.; Hall, J.E.; Gonen, T. Allosteric mechanism of water-channel gating by Ca2+-calmodulin. Nat. Struct. Mol. Biol. 2013, 20, 1085-1092. [CrossRef]

89. Fields, J.B.; Nemeth-Cahalan, K.L.; Freites, J.A.; Vorontsova, I.; Hall, J.E.; Tobias, D.J. Calmodulin Gates Aquaporin 0 Permeability through a Positively Charged Cytoplasmic Loop. J. Biol. Chem. 2016, 292, 185-195. [CrossRef] [PubMed]

90. Reichow, S.L.; Gonen, T. Noncanonical binding of calmodulin to aquaporin-0: Implications for channel regulation. Structure 2008, 16, 1389-1398. [CrossRef] [PubMed]

91. Babu, Y.S.; Bugg, C.E.; Cook, W.J. Structure of calmodulin refined at 2.2 A resolution. J. Mol. Biol. 1988, 204, 191-204. [CrossRef]

92. Kretsinger, R.H. Hipothesis: Calcium modulated proteins contain EF-hands. In Calcium Transport in Contraction and Secretion; Carafoli, E., Clementi, F., Drabinowski, W., Margreth, A., Eds.; Elsevier: Amsterdam, The Netherlands, 1975 ; pp. 469-478.

93. Zimmer, D.B.; Green, C.R.; Evans, W.H.; Gilula, N.B. Topological analysis of the major protein in isolated intact rat liver gap junctions and gap junction-derived single membrane structures. J. Biol. Chem. 1987, 262, 7751-7763. [CrossRef]

94. Elvira, M.; Villalobo, A. Calmodulin prevents the proteolysis of connexin32 by calpain. Bioelectrochem. Bioenerg. 1997, 42, 207-211. [CrossRef]

95. Diez, J.A.; Elvira, M.; Villalobo, A. The epidermal growth factor receptor tyrosine kinase phosphorylates connexin32. Mol. Cell. Biochem. 1998, 187, 201-210. [CrossRef]

96. Ahmad, S.; Martin, P.E.; Evans, W.H. Assembly of gap junction channels: Mechanism, effects of calmodulin antagonists and identification of connexin oligomerization determinants. Eur. J. Biochem. 2001, 268, 4544-4552. [CrossRef]

97. Peracchia, C. The calmodulin hypoyhesis for gap junction regulation six years later. In Gap Junctions; Hertzberg, E., Johnson, R.G., Eds.; Alan, R. Liss: New York, NY, USA, 1988; Volume 7, pp. 267-282.

98. Torok, K.; Trentham, D.R. Mechanism of 2-chloro-(epsilon-amino-Lys75)-[6-[4-(N,N- diethylamino)phenyl]-1,3,5-triazin-4yl]calmodulin interactions with smooth muscle myosin light chain kinase and derived peptides. Biochemistry 1994, 33, 12807-12820. [CrossRef]

99. Stauch, K.; Kieken, F.; Sorgen, P. Characterization of the structure and intermolecular interactions between the connexin 32 carboxyl-terminal domain and the protein partners synapse-associated protein 97 and calmodulin. J. Biol. Chem. 2012, 287, 27771-27788. [CrossRef]

100. Sorgen, P.L.; Trease, A.J.; Spagnol, G.; Delmar, M.; Nielsen, M.S. Protein-Protein Interactions with Connexin 43: Regulation and Function. Int. J. Mol. Sci. 2018, 19, 1428. [CrossRef]

101. Aseervatham, J.L.X.; Mitchell, C.K.; Lin, Y.-P.; Heidelberg, R.; O’Brian, J. Calmodulin binding to connexin 35: Specializations to function as an electrical synapse. Int. J. Mol. Sci. 2020, 21, 6346. [CrossRef]

102. Wei, S.; Cassara, C.; Lin, X.; Veenstra, R.D. Calcium-calmodulin gating of a pH-insensitive isoform of connexin 43 gap junctions. Biochem. J. 2019, 476, 1137-1148. [CrossRef]

103. Burr, G.S.; Mitchell, C.K.; Keflemariam, Y.J.; Heidelberger, R.; O’Brien, J. Calcium-dependent binding of calmodulin to neuronal gap junction proteins. Biochem. Biophys. Res. Commun. 2005, 335, 1191-1198. [CrossRef]

104. Siu, R.C.; Smirnova, E.; Brown, C.A.; Zoidl, C.; Spray, D.C.; Donaldson, L.W.; Zoidl, G. Structural and Functional Consequences of Connexin 36 (Cx36) Interaction with Calmodulin. Front. Mol. Neurosci. 2016, 9, 120. [CrossRef] 
105. Gonzalez-Nieto, D.; Gomez-Hernandez, J.M.; Larrosa, B.; Gutierrez, C.; Munoz, M.D.; Fasciani, I.; O’Brien, J.; Zappala, A.; Cicirata, F.; Barrio, L.C. Regulation of neuronal connexin-36 channels by pH. Proc. Natl. Acad. Sci. USA 2008, 105, 17169-17174. [CrossRef]

106. Li, S.; Hao, B.; Lu, Y.; Yu, P.; Lee, H.C.; Yue, J. Intracellular alkalinization induces cytosolic Ca2+ increases by inhibiting sarco/endoplasmic reticulum Ca2+-ATPase (SERCA). PLoS ONE 2012, 7, e31905. [CrossRef]

107. Rose, B.; Rick, R. Intracellular pH, intracellular free Ca, and junctional cell-cell coupling. J. Membr. Biol. 1978, 44, 377-415. [CrossRef]

108. Wang, X.G.; Peracchia, C. Connexin 32/38 chimeras suggest a role for the second half of inner loop in gap junction gating by low pH. Am. J. Physiol. 1996, 271, C1743-C1749. [CrossRef]

109. Wang, X.; Li, L.; Peracchia, L.L.; Peracchia, C. Chimeric evidence for a role of the connexin cytoplasmic loop in gap junction channel gating. Pflug. Arch. 1996, 431, 844-852. [CrossRef]

110. Myllykoski, M.; Kuczera, K.; Kursula, P. Complex formation between calmodulin and a peptide from the intracellular loop of the gap junction protein connexin43: Molecular conformation and energetics of binding. Biophys. Chem. 2009, 144, 130-135. [CrossRef]

111. Peracchia, C.; Chen, J.T.; Peracchia, L.L. $\mathrm{CO}_{2}$ sensitivity of voltage gating and gating polarity of gapjunction channels—connexin40 and its COOH-terminus-truncated mutant. J. Membr. Biol. 2004, 200, 105-113. [CrossRef]

112. Peracchia, C.; Wang, X.C.; Peracchia, L.L. Behavior of chemical and slow voltage-gates of connexin channels. The cork gating hypothesis. In Gap Junctions-Molecular Basis of Cell Comunication in Health and Disease; Peracchia, C., Ed.; Academic Press: San Diego, CA, USA, 2000; pp. 271-295.

113. Peracchia, C. Calmodulin-cork model of gap junction channel gating-One molecule, two mechanisms. Int. J. Mol. Sci. 2020, 21, 4938. [CrossRef]

114. Peracchia, C.; Wang, X.G.; Peracchia, L.L. Is the chemical gate of connexins voltage sensitive? Behavior of Cx32 wild-type and mutant channels. Am. J. Physiol. 1999, 276, C1361-C1373. [CrossRef]

115. Hu, Z.; Riquelme, M.A.; Wang, B.; Bugay, V.; Brenner, R.; Gu, S.; Jiang, J.X. Cataract-associated Connexin 46 Mutation Alters Its Interaction with Calmodulin and Function of Hemichannels. J. Biol. Chem. 2018, 293, 2573-2585. [CrossRef]

116. Fujimoto, K.; Araki, N.; Ogawa, K.S.; Kondo, S.; Kitaoka, T.; Ogawa, K. Ultracytochemistry of calmodulin binding sites in myocardial cells by staining of frozen thin sections with colloidal gold-labeled calmodulin. J. Histochem. Cytochem. 1989, 37, 249-256. [CrossRef]

117. Fleishman, S.J.; Unger, V.M.; Yeager, M.; Ben-Tal, N. A Calpha model for the transmembrane alpha helices of gap junction intercellular channels. Mol. Cell 2004, 15, 879-888. [CrossRef]

118. Perkins, G.; Goodenough, D.; Sosinsky, G. Three-dimensional structure of the gap junction connexon. Biophys. J. 1997, 72 Pt 1 , 533-544. [CrossRef]

119. Maeda, S.; Nakagawa, S.; Suga, M.; Yamashita, E.; Oshima, A.; Fujiyoshi, Y.; Tsukihara, T. Structure of the connexin 26 gap junction channel at 3.5 A resolution. Nature 2009, 458, 597-602. [CrossRef]

120. Makowski, L.; Caspar, D.L.; Goodenough, D.A.; Phillips, W.C. Gap Junction Structures: III. The Effect of Variations in the Isolation Procedure. Biophys. J. 1982, 37, 189-191. [CrossRef]

121. Makowski, L. Structural domains in gap junctions: Implications for the control of intercellular communication. In Gap Junction; Bennett, M.V.L., Ed.; Cold Spring Harbor Laboratories: Cold Spring Harbor, NY, USA, 1985; pp. 5-12.

122. Makowski, L.; Caspar, D.L.; Phillips, W.C.; Goodenough, D.A. Gap junction structures. V. Structural chemistry inferred from X-ray diffraction measurements on sucrose accessibility and trypsin susceptibility. J. Mol. Biol. 1984, 174, 449-481. [CrossRef]

123. Bukauskas, F.F.; Peracchia, C. Two distinct gating mechanisms in gap junction channels: CO2-sensitive and voltage-sensitive. Biophys. J. 1997, 72, 2137-2142. [CrossRef]

124. Peracchia, C.; Salim, M.; Peracchia, L.L. Unusual slow gating of gap junction channels in oocytes expressing connexin32 or its COOH-terminus truncated mutant. J. Membr. Biol. 2007, 215, 161-168. [CrossRef] [PubMed]

125. Persechini, A.; Gansz, K.J.; Paresi, R.J. Activation of myosin light chain kinase and nitric oxide synthase activities by engineered calmodulins with duplicated or exchanged EF hand pairs. Biochemistry 1996, 35, 224-228. [CrossRef] [PubMed]

126. Astegno, A.; La, V.V.; Marino, V.; Dell'Orco, D.; Dominici, P. Biochemical and biophysical characterization of a plant calmodulin: Role of the N- and C-lobes in calcium binding, conformational change, and target interaction. Biochim. Biophys. Acta 2016, 1864, 297-307. [CrossRef]

127. Peracchia, C. Gap junctions. Structural changes after uncoupling procedures. J. Cell Biol. 1977, 72, 628-641. [CrossRef]

128. Peracchia, C.; Dulhunty, A.F. Low resistance junctions in crayfish. Structural changes with functional uncoupling. J. Cell Biol. 1976, 70 Pt 1, 419-439. [CrossRef]

129. Peracchia, C. Low resistance junctions in crayfish. I. Two arrays of globules in junctional membranes. J. Cell Biol. 1973, 57, 66-76. [CrossRef]

130. Peracchia, C. Low resistance junctions in crayfish. II. Structural details and further evidence for intercellular channels by freeze-fracture and negative staining. J. Cell Biol. 1973, 57, 54-65. [CrossRef]

131. Bukauskas, F.F.; Angele, A.B.; Verselis, V.K.; Bennett, M.V. Coupling asymmetry of heterotypic connexin 45/ connexin 43-EGFP gap junctions: Properties of fast and slow gating mechanisms. Proc. Natl. Acad. Sci. USA 2002, 99, 7113-7118. [CrossRef] 
132. Bernardini, G.; Peracchia, C. Gap junction crystallization in lens fibers after an increase in cell calcium. Investig. Ophthalmol. Vis. Sci. 1981, 21, 291-299.

133. Black, D.J.; Tran, Q.K.; Persechini, A. Monitoring the total available calmodulin concentration in intact cells over the physiological range in free Ca2+. Cell Calcium 2004, 35, 415-425. [CrossRef]

134. Wu, X.; Bers, D.M. Free and bound intracellular calmodulin measurements in cardiac myocytes. Cell Calcium 2007, 41, 353-364. [CrossRef]

135. Peracchia, C. Gap junction channelopathies and calmodulinopathies. Do disease-causing calmodulin mutants affect direct cell-cell communication? Int. J. Mol. Sci. 2021, 22, 9169. [CrossRef]

136. Nyegaard, M.; Overgaard, M.T.; Sondergaard, M.T.; Vranas, M.; Behr, E.R.; Hildebrandt, L.L.; Lund, J.; Hedley, P.L.; Camm, A.J.; Wettrell, G.; et al. Mutations in calmodulin cause ventricular tachycardia and sudden cardiac death. Am. J. Hum. Genet. 2012, 91, 703-712. [CrossRef]

137. Jensen, H.H.; Brohus, M.; Nyegaard, M.; Overgaard, M.T. Human Calmodulin Mutations. Front. Mol. Neurosci. 2018, 11, 396. [CrossRef]

138. Badone, B.; Ronchi, C.; Kotta, M.C.; Sala, L.; Ghidoni, A.; Crotti, L.; Zaza, A. Calmodulinopathy: Functional Effects of CALM Mutations and Their Relationship With Clinical Phenotypes. Front. Cardiovasc. Med. 2018, 5, 176. [CrossRef]

139. Kotta, M.C.; Sala, L.; Ghidoni, A.; Badone, B.; Ronchi, C.; Parati, G.; Zaza, A.; Crotti, L. Calmodulinopathy: A Novel, LifeThreatening Clinical Entity Affecting the Young. Front. Cardiovasc. Med. 2018, 5, 175. [CrossRef]

140. Chazin, W.J.; Johnson, C.N. Calmodulin Mutations Associated with Heart Arrhythmia: A Status Report. Int. J. Mol. Sci. 2020, 21, 1418. [CrossRef]

141. Crotti, L.; Spazzolini, C.; Tester, D.J.; Ghidoni, A.; Baruteau, A.E.; Beckmann, B.M.; Behr, E.R.; Bennett, J.S.; Bezzina, C.R.; Bhuiyan, Z.A.; et al. Calmodulin mutations and life-threatening cardiac arrhythmias: Insights from the International Calmodulinopathy Registry. Eur. Heart J. 2019, 40, 2964-2975. [CrossRef] 